Article

\title{
The Importance of Considering Product Loss Rates in Life Cycle Assessment: The Example of Closure Systems for Bottled Wine
}

\section{Anna Kounina ${ }^{1,2, *}$, Elisa Tatti ${ }^{1}$, Sebastien Humbert ${ }^{1}$, Richard Pfister ${ }^{3}$, Amanda Pike ${ }^{4}$, Jean-François Ménard ${ }^{5}$, Yves Loerincik ${ }^{1}$ and Olivier Jolliet ${ }^{1}$}

1 Quantis, Parc Scientifique EPFL, Bâtiment D, 1015 Lausanne, Switzerland;

E-Mails: elisa.tatti@gmail.com (E.T.); sebastien.humbert@quantis-intl.com (S.H.);

yves.loerincik@quantis-intl.com (Y.L.); olivier.jolliet@quantis-intl.com (O.J.)

2 Swiss Federal Institute of Technology Lausanne (EPFL), 1015 Lausanne, Switzerland

3 Praxis Energia, rue Verte, 1261 Le Vaud, Switzerland;

E-Mail: richard.pfister@praxisenergia.ch

4 Quantis, 283 Franklin St. Floor 2, Boston, MA 02110, USA;

E-Mail: amanda.pike@quantis-intl.com

5 Quantis, 395 rue Laurier Ouest, Montréal, Québec, H2V 2K3, Canada;

E-Mail: jean-francois.menard@polymtl.ca

* Author to whom correspondence should be addressed; E-Mail: anna.kounina@quantis-intl.com; Tel.: +41-21-693-91-95; Fax: +41-21-693-91-96.

Received: 23 July 2012; in revised form: 21 September 2012 / Accepted: 2 October 2012 /

Published: 18 October 2012

Abstract: Purpose: The objective of this study is to discuss the implications of product loss rates in terms of the environmental performance of bottled wine. Wine loss refers to loss occurring when the consumer does not consume the wine contained in the bottle and disposes of it because of taste alteration, which is caused by inadequate product protection rendering the wine unpalatable to a knowledgeable consumer. The decision of whether or not to drink the wine in such cases is guided by subjective consumer taste perception and wine quality expectation (drinking the bottle or disposing of the wine down the drain and replacing it with a new bottle). This study aims to illustrate the importance of accurately defining system boundaries related to wine packaging systems. Methods: The environmental impacts resulting from wine loss rates as related to two types of wine bottle closures - natural cork stoppers and screw caps-have been estimated based on literature review data and compared to the impact of the respective closure system. 
The system studied relates to the functional unit "a $750 \mathrm{~mL}$ bottle of drinkable wine" and includes bottled wine, bottle and closure production, wine production, wine loss and wine poured down the drain. Results: The range of wine alteration rates due to corked wine is estimated to be $2-5 \%$ based on interviews with wine experts. Consumer behavior was assessed through a sensitivity study on replacement rates. When the increase in loss rate with the cork stopper is higher than $1.2 \%$ (corresponding to $3.5 \%$ corked wine multiplied by a consumer replacement rate of $35 \%$ ), the influence of losses on the impact results is higher than that of the closure material itself. The different closures and associated wine losses represent less than $5 \%$ of the total life cycle impact of bottled wine.

Keywords: life cycle assessment; losses; wine; closure; packaging; cork stopper; screw cap; system boundaries

\section{Introduction}

\section{Context and Objectives}

The environmental impacts of wine have been assessed by several studies [1-15]. Some of the studies consider the environmental impacts of different closure systems and offer comparative conclusions $[16,17]$. However, different types of closures, such as natural cork stoppers, synthetic stoppers or screw caps, have different properties, offering different levels of product protection and consequently presenting more or less risk for wine losses. To date, the influence of the closure type on the overall environmental impacts of bottled wine, taking losses into account, has not been studied in a life cycle assessment context.

In this study, wine loss refers to loss occurring when the consumer does not consume the wine contained in the bottle and disposes of it because of taste alteration, which is caused by inadequate product protection rendering the wine unpalatable to a knowledgeable consumer. When studying different bottled wine systems, it is essential to ensure that the compared systems are functionally equivalent and therefore, there is a need to consider the differences in wine loss rates due to better or worse product protection due to the closure. This study addresses this need and analyses the influence of closures on the environmental impacts of bottled wine, accounting for differences in loss rates for two selected closure systems: cork stoppers and screw caps, as shown in Figure 1.

The objective of this study is to discuss the implications of loss rates in terms of environmental performance depending on the closure type of the bottled wine system. Considering the entire system contributes to providing reliable and fair results for sustainable product design, branding and marketing. We quantify both the life cycle environmental profile of the closure itself and the impacts related to the differences in wine loss rates for each closure. Environmental impacts associated with wine losses are derived from the environmental impact of typical bottled wine with a defined quality, based on a literature review. The difference in wine alteration rates was estimated based on interviews with experts performed at universities and laboratories as well as a literature review $[18,19]$. 
Figure 1. Cork stopper and screw cap closures.

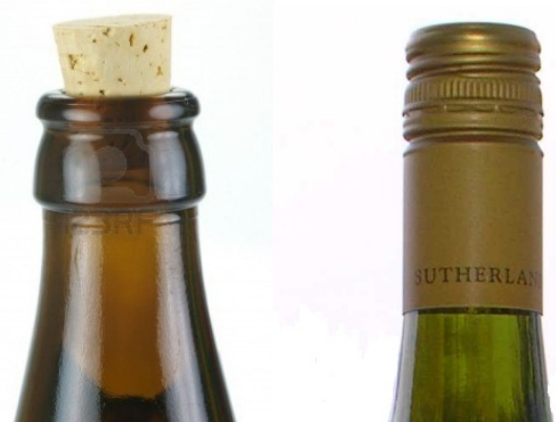

\section{Method}

\subsection{Closure Systems Considered and Functional Unit}

The most wide-spread closure systems used in the world market [20] are (1) cork stoppers (approximately $60 \%$ of world market), (2) synthetic stoppers (approximately 30\% of world market), and (3) screw caps (approximately 10\% of world market). "Crown stoppers" are used only for low-end wines or during the manufacturing of effervescent wines and therefore their market share is negligible. In this study, two types of closures were chosen (cork stoppers and screw caps) and their impacts were compared based on their material properties as well as their respective wine loss rates.

The system studied relates to the functional unit "a $750 \mathrm{~mL}$ bottle of drinkable wine" and includes the following main components:

- wine bottle production

- $750 \mathrm{~mL}$ of wine

- wine closure production

- wine loss associated with the closure systems

- wine poured down the drain

Other studies considering a delivered bottled wine as a functional unit did not consider if bottled wine quality affected whether or not the consumer would actually drink the wine. Quantities of bottled wine produced were recalculated for all closure types based on the equivalent functional unit of $750 \mathrm{~mL}$ of drinkable bottled wine, thus including wine losses. This functional unit allows for the comparison of studies evaluating the life cycle impact of bottled wine production, as well as the consideration of wine loss rates due to different types of closures.

\subsection{System Boundaries and Bottled Wine Production}

The studied system includes the raw material extraction, vineyard operations, delivery, closure and packaging manufacturing, winery operations, distribution, consumer purchasing and packaging end of life (Figure 2). The wine poured down the drain is included in the system, and the related model is described in Section 2.4. 
Figure 2. System for bottled wine and its closure system including the different life cycle stages.

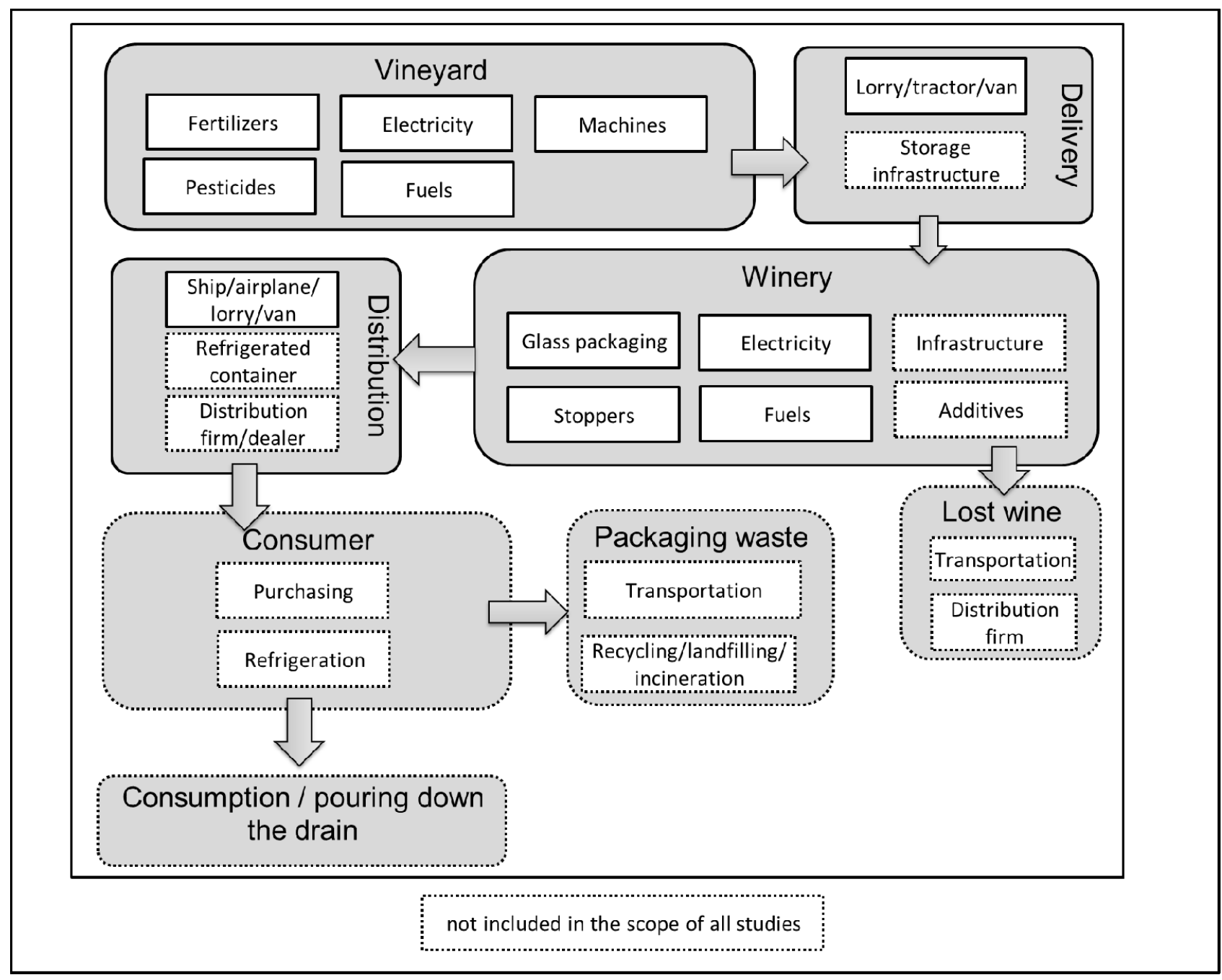

A literature review has been performed on studies assessing the life cycle impact of wine production, independent of the closure type [1-10]. Only the vineyard operations, delivery, winery and distribution stages are taken into account in all these studies. Management of the waste generated by the vineyard, retail functioning and infrastructure, reclosing opened bottles, vineyard and winery overheads (offices, employee commuting and business travels, marketing, advertising, and other administrative functions), as well as wine glass use and washing are not taken into account in all studies and are therefore not considered in this literature review comparison. Part of the ethanol consumed by humans and converted to $\mathrm{CO}_{2}$ by human metabolism represents biogenic $\mathrm{CO}_{2}$ and has not been considered in this system.

The reviewed studies present different indicators to assess the environmental impact of wine. In order to ensure the highest level of comparability among the analyzed references, this literature review focuses on the following indicators that were assessed in most of the reference studies: 
1. Global warming over 100 years (in $\mathrm{kg} \mathrm{CO}_{2} \mathrm{eq}$ )

2. Non-renewable primary energy use (in MJ)

3. Atmospheric acidification (in $\mathrm{g} \mathrm{H}^{+}$eq)

4. Photo-oxidant formation (in $\mathrm{kg}$ ethylene eq)

5. Eutrophication of surface water (in $\mathrm{kg} \mathrm{PO}_{4}{ }^{3-} \mathrm{eq}$ )

These indicators are included in the International Reference Life Cycle Data System (ILCD) framework for impact categories for characterization modeling at midpoint [21]. Although the studies consulted provide an essential basis for gaining an understanding of the overall environmental impact of wine production, they also have some important limitations. They do not all have the same scope or system boundaries, nor do they use the same impact assessment method. However, as the impact results on common indicators have the same order of magnitude, the differences in scope and system boundaries are not significant enough to prevent them being used for this case study. For other applications, care must be taken if results are to be used to determine the absolute impact of a bottle of wine.

A detailed description of the results of the literature review can be found in the supporting information Section S1.

\subsection{Wine Closure Production}

The impacts of closure systems (including production of raw materials, transport of raw materials, manufacturing of closures, transport of closures, bottling and end-of-life) are directly taken from the Corticeira study [17].

\subsection{Wine Loss Associated with the Closure Systems}

Physical losses which occur during filling, packaging, and transporting (breaking bottles, spilling wine) and which are independent of closure types are not taken in account in this study, which focuses solely on the influences of different closure types. Physical failures during all life cycle stages which result in wine alteration, e.g., poor storing of closures, poor calibration of the bottling machinery or transport in inappropriate conditions (such as inappropriate temperature, exposure to the sun or humidity, etc.), are considered and summarized in supporting information in Table S2, where the fraction of wine taste alteration per stage has been estimated.

Wine taste alteration occurs when the contents of a bottle acquires an altered taste, either due to inadequate protection allowing for oxidation of the content or via a reaction with the closure material, such that the consumer decides not to drink it and disposes of it. For this study, the level of wine loss is estimated by multiplying the following two parameters:

1. Percentage of bottles with an altered taste (Section 2.4.1). This parameter depends on the type of closure as well as wine conservation failures during its life cycle.

2. Percentage of the bottles with an altered taste that are actually thrown away by the consumer (Section 2.4.2 on consumer behavior). This parameter depends on the consumer, their expertise and sensitivity to recognize the altered taste (due to the wide range of alteration intensity). 


\subsubsection{Taste Alterations Considered and Fraction of Bottles with Altered Tastes}

The taste alterations considered in this study are those discovered by the consumer or sommelier. Taste alterations can occur throughout the entire life cycle of bottled wine, from storage in a wine cellar to the consumer's glass. The following closure system failures can be distinguished at the consumer level:

1. an undesirable odor due to failures at different life cycle stages (e.g., incorrect transport or storage in inappropriate locations before and after the bottling process);

2. an unfavorable taste due to conservation problems (e.g., being stored too long);

3. a "corked" taste.

Several "corked tastes" are possible and appear with differing frequencies. A description of each is as follows:

a. A "true corked taste"- or "goût de bouchon"-is due to the presence of the fungus Armillaria mellea [22] and is characterized by a powerful taste which makes the wine undrinkable; this is also known as "yellow stain";

b. A "taste of cork" occurs when wine elements are affected by the cork. The wine is considered altered when it is too intense;

c. A "mould taste" is caused by microorganisms on the cork (e.g., Aspergillus and Penicillium), which affect the organoleptic character of wine [23,24];

d. A "false corked taste" is due to 2,4,6-trichloroanisol (TCA), which is synthesized by the fungi Penicillium from chlorophenols, which can enter cork during its production and/or storage.

Mold tastes and false corked tastes are the most frequent wine alterations.

Cork stoppers: Wine taste alteration due to cork stoppers is primarily due to the presence of fungus which results in the "corked taste" [19]. Wine taste alteration can also occur during transport, storage, cork machine adjustment as well as when the cork's lifespan is exceeded. Undesirable odors are often erroneously attributed to the "true cork taste", which causes considerable uncertainty in the percentage of bottles affected by this phenomenon [25]. In addition, there are three types of cork stoppers (chipboard cork, natural cork, and cork treated with supercritical carbon dioxide) [26-28] that can cause variable taste alteration, making it yet more difficult to determine with certainty that wines possess the "true corked taste".

Given these uncertainties, taste alteration rates due to cork stoppers can be only approximately estimated using expert judgment. Seven interviews were carried out and complemented with two literature sources to serve as primary data for determining the respective fractions of bottled wine with altered tastes for the two types of closures studied. Experts from cellar quality control consultancies, laboratories and various institutes specialized in bottling or cellar quality control were interviewed. Their estimations for wine alteration rates are listed in the supporting information S2. The share of bottles with cork stoppers having an altered taste is estimated to be between $2 \%$ and $5 \%$, where the lower and higher values correspond to the medians of the limits provided by the experts and literature sources. This range reflects the variability of existing cork stopper quality, their treatment, and the 
sensitivity of the type of wine to taste alteration.

Screw caps: Unpleasant odors due to the reduction of wine can occur if the choice of the screw cap liner is not appropriate. Several types of liners exist with various degrees of permeability and are normally tailored to the specific application. Based on discussions with the same companies specialized in bottling or cellar quality control, the taste alteration rate with the screw caps is reduced by a factor 5 to 10 compared to the cork stoppers (see detailed in supporting information S2). The share of bottles with screw caps having an altered taste is therefore estimated to be lower than that for cork stoppers by a factor of 7.5 times (i.e., between $0.3 \%$ and $0.7 \%$ of bottles). However, we have included in the analysis a broad loss range (from a factor 5 to 10 times less than cork stoppers) and considered a triangular distribution (5 times lower (maximum), 7.5 times (mean) and 10 times (minimum)) for the modeling in order to consider the uncertainty resulting from all input parameters variability.

An estimation of the life cycle stage at which the failure originated is provided in the supporting information S3. We acknowledge the limitations of data availability on the respective taste alteration rates due to different closure types. However, the order of magnitude of the relative wine taste alteration rates for both types of closures estimated by the expert sources consulted are considered sufficiently robust for them to be used in this study. For this reason, we have carried out a sensitivity study looking at the lower and upper range of effective losses considered.

\subsubsection{Consumer Behavior}

In this study, it is assumed that altered wine odors or tastes result in different consumer behaviors which are guided by subjective taste perception, wine quality expectation and whether the consumer is a sommelier or a regular consumer (recognizing that the latter will also have a range of behaviors). These behaviors could include:

1. Drinking the bottle (considered unlikely for a strongly "corked" bottled wine)

2. Disposal of the wine down the drain (or returning it to the store before eventual disposal at the store) and opening a new bottle. Thus, this particular behavior increases the amount of wine needed to fulfill the functional unit

In the reference scenario, the consumer behavior is estimated based on a combination of literature data and expert judgment. The European average for consumers who would drink the bottle without considering wine to be "altered" is based on the MIS Trend study [29] which estimated that 23\% of Swiss consumers considering themselves as not knowledgeable about wine. The other $77 \%$ would replace a bottle of wine with an altered taste with a new bottle. With these insights, an estimated effective wine loss between 1.5 and $3.8 \%$ for cork stoppers and between 0.21 and $0.51 \%$ for screw caps were determined.

To complement this reference scenario and to test the sensitivity of impacts to changes in wine taste alteration and replacement rates, we carried out a sensitivity study looking at the impact variations of the cork and screw cap closures as a function of these rates. Based on this analysis, environmental preference can be deduced for replacement rates based on specific consumer behavior patterns. 


\subsection{Impacts of Wine Poured Down the Drain}

Two types of emissions are considered when the bottled wine with altered taste is poured in the sewage system: (1) direct emissions, i.e., methane emissions which occur from the sewage and wastewater treatment plant and (2) indirect emissions, i.e., from functioning of the wastewater treatment plant and its related electricity and chemicals production. Direct $\mathrm{CO}_{2}$ emissions are not considered since this represents biogenic $\mathrm{CO}_{2}$ that has been fixed earlier during wine production (not considered in the literature sources for bottled wine production), leading to a zero net emission over the wine life cycle.

Direct emissions: Wine that is poured down the drain consists of organic compounds, mainly ethanol (estimated at $10 \%$ of the wine by volume), which is broken down into carbon dioxide $\left(\mathrm{CO}_{2}\right)$, and, under anaerobic conditions, into methane $\left(\mathrm{CH}_{4}\right)$ in the sewage system and the anaerobic sludge digester. The calculation details for the initial amount of carbon $(31 \mathrm{~g})$ poured into the sewage system are specified in supporting information S4. Figure 3 shows the emissions of methane and carbon dioxide due to wine poured down the drain and entering the wastewater treatment plant (in $\%$ of carbon originally present in the wine, based on SimpleTreat 3.1 model [30]). Input and output parameters are summarized in supporting information S4. The Dutch Ministry of Housing, Spatial Planning and the Environment (VROM) [31,32] estimates that $0.7 \%$ of the COD mass is converted to $\mathrm{CH}_{4}$ in a wastewater treatment plant without anaerobic sludge digestion based on the IPCC inventory guidelines [33]. This corresponds to $2.8 \% \mathrm{~kg} \mathrm{CH}_{4}$ per $\mathrm{kg}$ TOC, using the ratio $4 \mathrm{~g} \mathrm{COD} / \mathrm{g}$ TOC (estimation explained in the supporting information 4). Given the limitation in data availability on ethanol degradation and methane production in the sewage system, we considered the sewage and wastewater treatment system as a single system with the same physical and biological processes. Total methane emissions to air from wine poured down the drain represent $2.9 \mathrm{E}-2 \mathrm{~kg} \mathrm{CO} \mathrm{C}_{2}$ eq per bottle as the contribution to the global warming impact category, knowing that the methane global warming potential is $25 \mathrm{~kg} \mathrm{CO}_{2} \mathrm{eq} / \mathrm{kg}$ methane considering a 100 -year time horizon. Carbon emissions to water after wastewater treatment produce $3.4 \mathrm{E}-4 \mathrm{~kg} \mathrm{PO}_{4}{ }^{3-} /$ bottle poured down the drain as the contribution to freshwater eutrophication. The latter impact score is calculated assuming an emission of $12.6 \%$ of the initial ethanol amount in the effluent (based on SimpleTreat 3.1 model), a chemical oxygen demand/total organic carbon ratio of 4 , and using the IMPACT $2002+$ factor $0.022 \mathrm{~kg} \mathrm{PO}_{4}{ }^{3-} / \mathrm{kg}$ COD [34].

Figure 3. Methane and carbon dioxide emissions (associated with carbon contained in ethanol) due to wine poured down the drain and treated at the wastewater treatment plan.

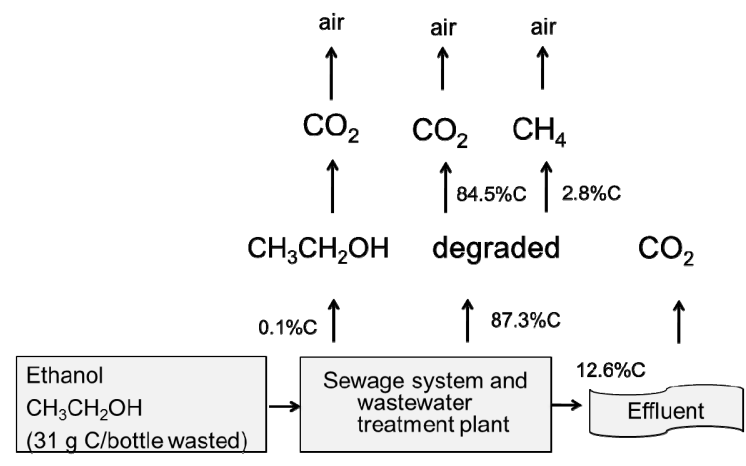


Indirect emissions: In addition, emissions also occur during the treatment processes. Values from ecoinvent v 2.2 are used in this study and assume that an average of $750 \mathrm{~mL}$ of tap water is used in addition to $750 \mathrm{~mL}$ of bottled wine wasted. The global warming score associated with the tap water production $(750 \mathrm{~mL} /$ bottle wasted $)$ and the wastewater treatment plant operation $(2 \times 750 \mathrm{~mL} /$ bottle wasted) is very low, estimated at $6.3 \mathrm{E}-4 \mathrm{~kg} \mathrm{CO}$ eq/bottle wasted.

\section{Results}

\subsection{Impact Scores for Wine Production, Closures and Wine Poured Down the Drain}

Table 1 presents the impacts of the production of $750 \mathrm{~mL}$ of wine, the impacts of closure production and the impacts due to $750 \mathrm{~mL}$ wine being poured down the drain, which were obtained from the literature review. The latter value needs to be multiplied by the loss rate in order to be related to the functional unit.

Table 1. Impact scores for wine production, closure production and wine poured down the drain.

\begin{tabular}{|c|c|c|c|c|c|}
\hline \multirow{2}{*}{$\begin{array}{l}\text { Impact category } \\
\text { studied }\end{array}$} & \multicolumn{2}{|c|}{$\begin{array}{c}750 \mathrm{ml} \text { bottled wine } \\
\text { production } \\
{[1-10]}\end{array}$} & \multicolumn{2}{|c|}{ Closure production [17] } & \multirow{2}{*}{$\begin{array}{c}\text { Wine poured down the } \\
\text { drain (recalculated based } \\
\text { on ecoinvent v2.2) } \\
\text { For } 750 \mathrm{~mL} \text { of wine }\end{array}$} \\
\hline & average & range & Cork stopper & Screw cap & \\
\hline $\begin{array}{c}\text { Global warming } \\
\left(\mathrm{kg} \mathrm{CO}_{2} \mathrm{eq}\right)\end{array}$ & 3.3 & $1.0-4.0$ & $2.0 \mathrm{E}-3$ & $3.7 \mathrm{E}-2$ & 2.9E-2 \\
\hline $\begin{array}{c}\text { Non-renewable } \\
\text { energy use } \\
\text { (MJ) }\end{array}$ & 47 & $16-58$ & 0.10 & 0.44 & $1.1 \mathrm{E}-3$ \\
\hline $\begin{array}{l}\text { Atmospheric } \\
\text { acidification } \\
\left(\mathbf{g ~ H}^{+} \text {eq }\right)\end{array}$ & 0.78 & $0.27-1.3$ & $1.3 \mathrm{E}-3$ & $8.2 \mathrm{E}-3$ & $\begin{array}{l}\text { 2.7E-4 } \\
\text { (Modeled with } \\
\text { TRACI [36]) }\end{array}$ \\
\hline $\begin{array}{c}\text { Photo-oxidant } \\
\text { formation } \\
\text { (kg ethylene eq) }\end{array}$ & $1.9 \mathrm{E}-03$ & $1.1 \mathrm{E}-3-2.3 \mathrm{E}-3$ & $3 \mathrm{E}-6$ & $1.4 \mathrm{E}-5$ & $1.6 \mathrm{E}-7$ \\
\hline $\begin{array}{c}\text { Eutrophication } \\
\left(\mathrm{kg} \mathrm{PO}_{4}{ }^{3-} \mathrm{eq}\right)\end{array}$ & $4.5 \mathrm{E}-03$ & $1.4 \mathrm{E}-3-7.8 \mathrm{E}-3$ & $6 \mathrm{E}-7$ & $7 \mathrm{E}-7$ & $3.5 \mathrm{E}-4$ \\
\hline
\end{tabular}

The environmental profile generated by the literature review shows that the closure system represents between $0.01 \%$ and $1.1 \%$ of the total score for the produced bottled wine, depending on the indicator and the type of closure. Although minimal, the closure contribution to the overall impact appears to be largest for the global warming and atmospheric acidification impact categories.

The contribution to different impact categories due to a bottle of wine poured down the drain vary between $0.002 \%$ and $7.7 \%$ (for eutrophication) of the total score for bottled wine depending on the indicator and the type of closure. Again, the latter value needs to be multiplied by the loss rate in order to be related to the functional unit. 


\subsection{Influence of the Wine Loss Rate Due to Different Closures}

The overall environmental performance of the closure in packing and preserving wine prior to its consumption combines the impacts from:

1. Losses at the consumer due to altered taste

2. Closure impacts according to the results of the Corticeira study [17]

3. Impacts related to sewage and wastewater treatment from wine loss

The reference scenario is based on the impact from wine losses when $77 \%$ of consumers replace the bottle when they encounter one with an altered taste. A sensitivity study was carried out to study the influence of replacement variation.

\subsubsection{Reference Scenario}

Figure 4 shows the results for the reference scenario, presenting the geometric mean value of the impact from the wine loss distribution (all parameters are modeled with a statistical distribution). Throughout the whole paper, the only common functional unit is $750 \mathrm{~mL}$ drinkable wine. Impacts of the bottled wine are not closure-specific and are equal for both closure systems. They can therefore be excluded from Figure 4 to focus result presentation on the influence of closures and related losses. The lost bottles of wine (i.e., the extra amount of wine needed to fulfill the function of having bottled drinkable wine) can contribute anywhere from $28 \%$ of the impacts of the closures themselves (e.g., in the case of screw caps for the global warming category) to several times more than the impact of the closures themselves (e.g., in the case of cork stoppers for all impact categories). When the wine loss rate is considered, the cork stopper presents a higher score than the screw cap for all impact categories.

An uncertainty analysis was performed to assess the variability of the impact for both systems. The relative ranking for all impact categories based on a 5000-run Monte Carlo assessment was also performed. The impact of wine, cork stoppers, screw caps and replacement rates are modeled with a triangular distribution. This distribution has been selected because (1) it is defined with a most probable value as well as a $95 \%$ confidence range and (2) it can be asymmetrical. The alteration rate for the cork stopper (estimated from 2 to $5 \%$ ) is modeled with a uniform distribution given there is no preferred value within this range. The alteration rate for the screw cap is estimated as 0.13 times the impact of the cork stopper (7.5 times less), with a triangular distribution between 0.1 and 0.2 times the impact of the cork stopper. The share of runs where the cork stopper system has a higher impact score than the screw cap system is specified in Table 2 for each impact category. Figure 5 displays the Monte Carlo analysis results for global warming where the cork stopper has a higher impact score than the screw cap stopper (red color) for $89.6 \%$ of the 5000 runs. More details on the uncertainty analysis parameters and results are included in the supporting information S5. 
Figure 4. Impact over the whole life cycle associated with $750 \mathrm{~mL}$ drinkable wine, for a $77 \%$ replacement rate, differentiated due to losses that can be attributed to the failure of different closure systems and the impact of the closure systems themselves (excluding the non-closure-specific impacts that are equal for all scenarios).
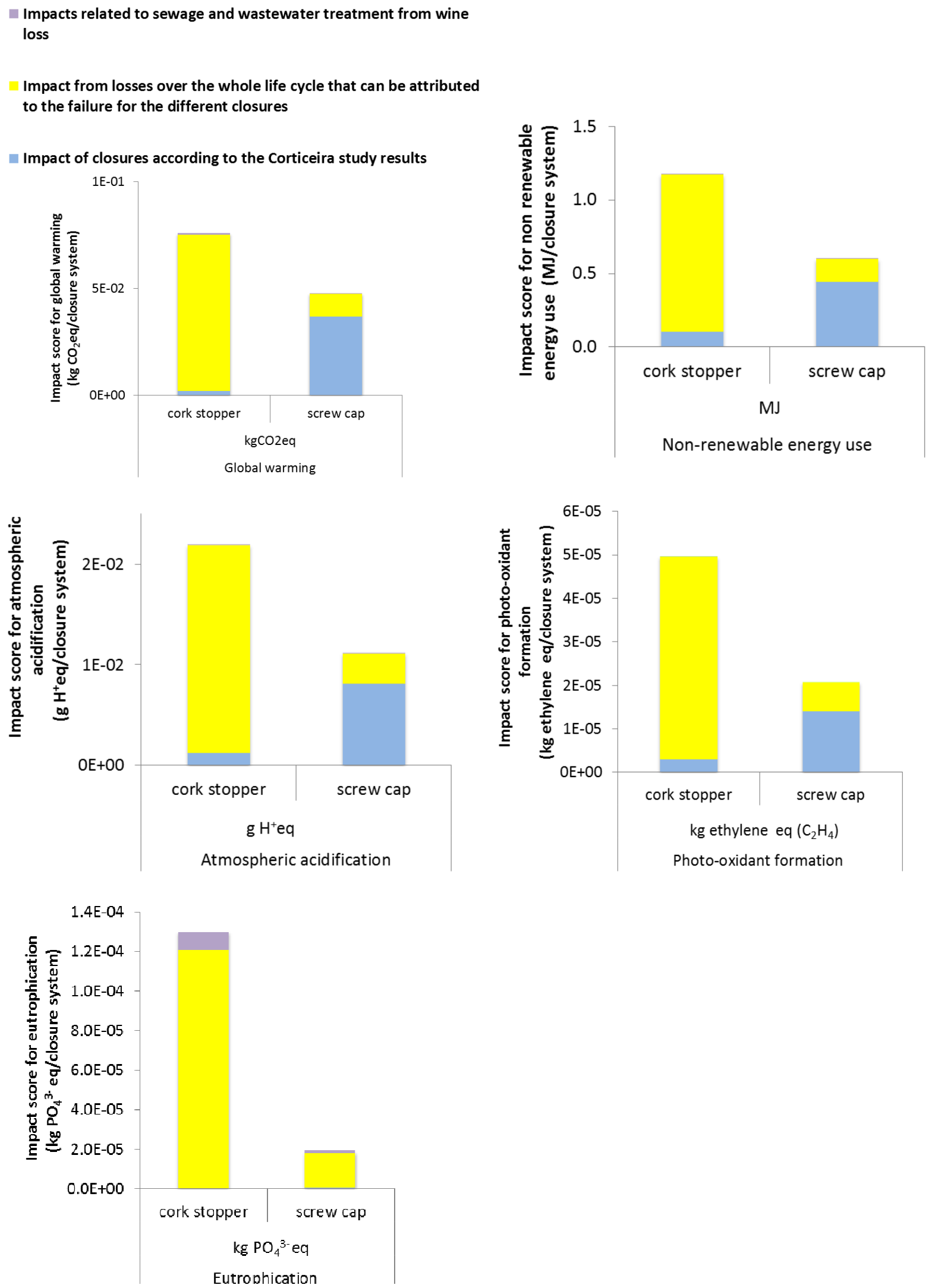
Figure 5. Monte Carlo analysis with 5000 runs for the cork and screw cap stopper systems for the global warming category.

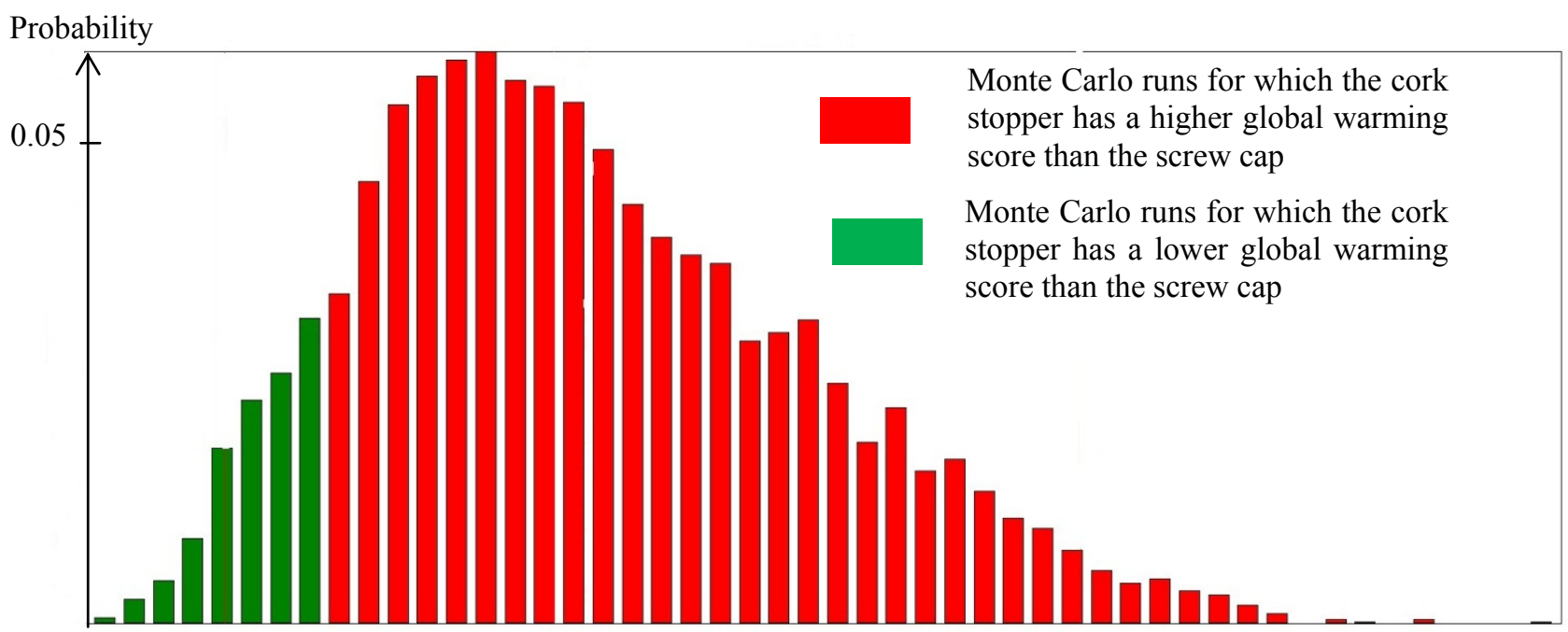

Figure 6 shows the overall contribution to the global warming impact category for bottled wine comparing the wine loss rates from the different closure systems and the closures based on the Corticeira study with the impact of the wine itself. The influence of the closure on the total impacts of bottled wine is relatively small. This explains why even a small difference in loss rates for the two types of closures can offset the impact score trend for the bottled wine and closure system originally in favor of cork stoppers. The overall impact of bottled wine shows the same trend for all impact indicators: the cumulative impact of the closure, the associated loss rate and the impacts related to sewage and wastewater treatment from wine loss, which represents less than $5 \%$ of the total impact of the whole bottled wine system.

Figure 6. Comparison of the closure production global warming scores, including the relative loss rates concerning the entire impacts associated with bottled wine.

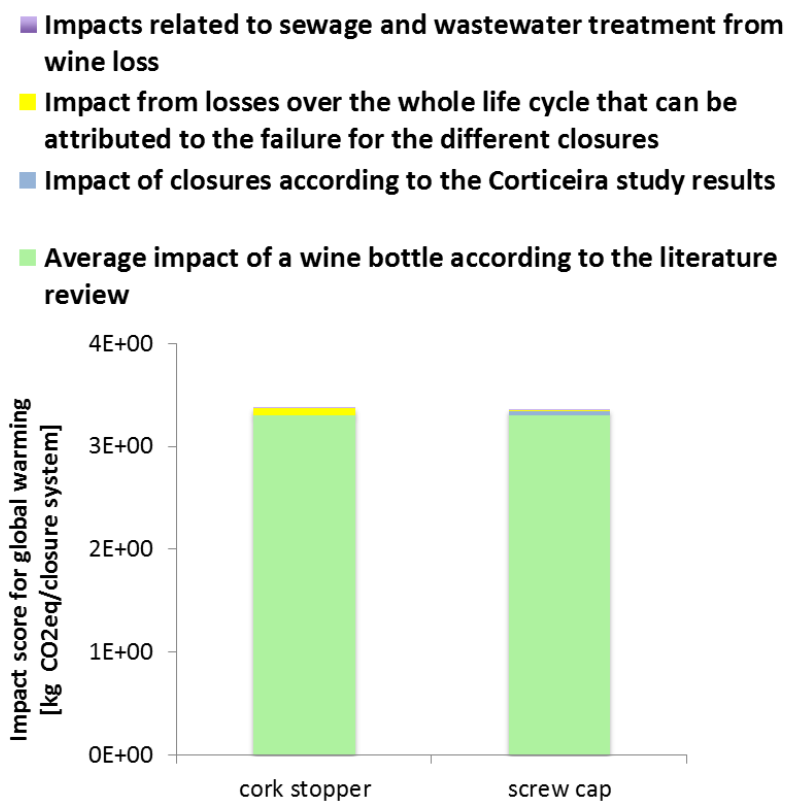




\subsubsection{Sensitivity Study}

Since the replacement and loss rates may vary widely depending on consumer behavior, it is important to perform a sensitivity study on how these rates influence the overall impact. Figure 7 shows the global warming impact score for the cork stopper compared to the screw cap as a function of the replacement rate, for low ( $2 \%$ for cork stopper, $0.3 \%$ for screw caps), medium (3.5\% for cork stopper, $0.5 \%$ for screw caps) and high (5\% for cork stopper, $0.7 \%$ for screw caps) wine taste alteration rates. At low replacement rates, the contribution of the screw cap to the global warming impact category is higher. As the replacement rates increases, impacts due to losses for the cork stopper are more important than for the screw cap. The break-even point is at a $35 \%$ replacement rate for the average wine alteration rate of $3.5 \%$. Thus, the product of these two rates leads to an effective loss rate of $1.2 \%$ for the cork stopper. This effective loss rate of $1.2 \%$ also corresponds to break-even points of $61 \%$ replacement for a low $(2 \%)$ taste alteration rate and to $24 \%$ for a high $(5 \%)$ taste alteration rate. At a higher replacement rate (e.g., the 77\% rate of the reference scenario), the screw cap system clearly becomes advantageous.

Figures and equations used for the sensitivity analysis to determine the break-even point for the other impact categories are provided in the supporting information S6. Table 2 summarizes the break-even points for replacement and effective loss rates for all impact categories. The replacement rates at the break-even points for photo-oxidant formation, non-renewable energy and atmospheric acidification are slightly lower than for global warming (19\% to $29 \%$ replacement rate and $0.67 \%$ to $1.0 \%$ effective loss rate for cork stoppers). The replacement rate is very low for eutrophication (less than $0.1 \%$ ). For any higher value than the break-even point, the impact of the cork stopper would exceed the impact of the screw cap.

Figure 7. Impact score for global warming of the cork stopper production compared to the screw cap production as a function of the replacement rate

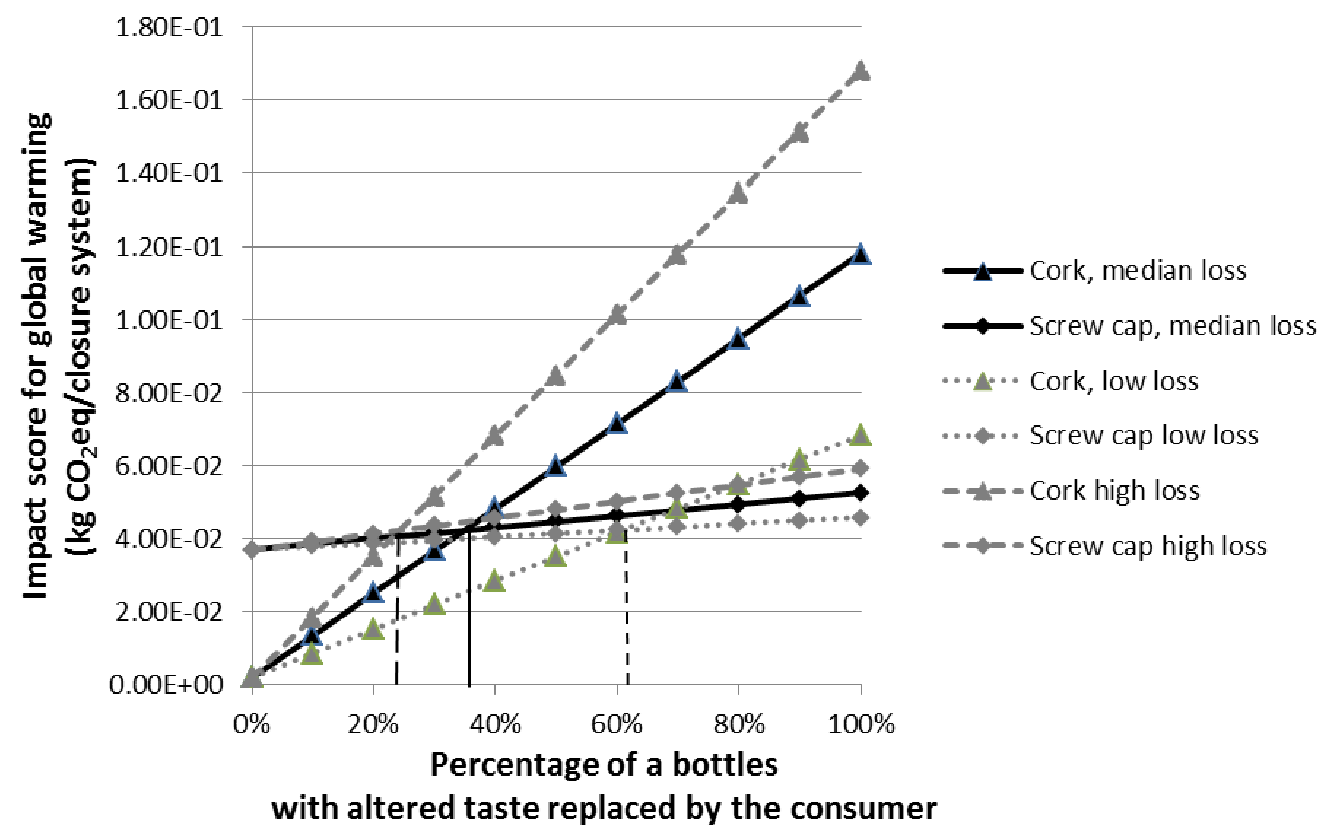




\subsubsection{Results Summary}

The results of the reference scenario uncertainty as well as the sensitivity analysis are shown in Table 2.

Table 2. Monte Carlo analysis results for the reference scenario and the break-even percentages for the replacement rate and the effective losses for the sensitivity analysis, for which the total impact of the screw cap is equal to the impact of the cork stopper.

\begin{tabular}{|c|c|c|c|}
\hline & Reference scenario & Sensitivit & analysis \\
\hline Indicator & $\begin{array}{l}\text { Monte Carlo } \\
\text { analysis: \% runs for } \\
\text { which the impact } \\
\text { score for cork } \\
\text { stoppers is higher } \\
\text { than for screw caps }\end{array}$ & $\begin{array}{l}\text { Break-even replacement } \\
\text { rates for which the impact } \\
\text { of the screw cap is equal to } \\
\text { the impact of the cork } \\
\text { stopper (bottles with } \\
\text { altered taste estimated as } \\
\mathbf{3 \%} \text { for cork stoppers and } \\
\text { as } 0.5 \% \text { for screw caps) }\end{array}$ & $\begin{array}{l}\text { Break-even effective loss } \\
\text { rates for which the } \\
\text { impact of screw cap is } \\
\text { equal to the impact of the } \\
\text { cork stopper }\end{array}$ \\
\hline $\begin{array}{l}\text { Global warming } \\
\left(\mathrm{kg} \mathrm{CO}_{2} \mathrm{eq}\right)\end{array}$ & $89.6 \%$ & $\begin{array}{c}35 \% \text { of consumers replace } \\
\text { the bottle }\end{array}$ & $\begin{array}{l}\text { Cork stopper: } 1.2 \% \text { of } \\
\text { wine bottles } \\
\text { Screw cap: } 0.16 \% \text { of } \\
\text { wine bottles }\end{array}$ \\
\hline $\begin{array}{l}\text { Non-renewable energy } \\
\text { use (MJ) }\end{array}$ & $98.4 \%$ & $\begin{array}{c}24 \% \text { of consumers replace } \\
\text { the bottle }\end{array}$ & $\begin{array}{l}\text { Cork stopper: } 0.83 \% \text { of } \\
\text { wine bottle } \\
\text { Screw cap: } 0.11 \% \text { of } \\
\text { wine bottles }\end{array}$ \\
\hline $\begin{array}{l}\text { Atmospheric } \\
\text { acidification } \\
\left(\mathrm{g} \mathrm{H}^{+} \text {eq }\right)\end{array}$ & $96.9 \%$ & $\begin{array}{c}29 \% \text { of consumers replace } \\
\text { the bottle }\end{array}$ & $\begin{array}{l}\text { Cork stopper: } 1.0 \% \text { of } \\
\text { wine bottle } \\
\text { Screw cap: } 0.14 \% \text { of } \\
\text { wine bottles }\end{array}$ \\
\hline $\begin{array}{l}\text { Photo-oxidant } \\
\text { formation } \\
\text { (kg ethylene eq) }\end{array}$ & $99.8 \%$ & $\begin{array}{c}19 \% \text { of consumers replace } \\
\text { the bottle }\end{array}$ & $\begin{array}{l}\text { Cork stopper: } 0.67 \% \text { of } \\
\text { wine bottle } \\
\text { Screw cap: } 0.09 \% \text { of } \\
\text { wine bottles }\end{array}$ \\
\hline $\begin{array}{l}\text { Eutrophication } \\
\left(\mathrm{kg} \mathrm{PO}_{4}{ }^{3-} \mathrm{eq}\right)\end{array}$ & $100 \%$ & $\begin{array}{c}0.07 \% \text { of consumers replace } \\
\text { the bottle }\end{array}$ & $\begin{array}{l}\text { Cork stopper: } 0.0026 \% \text { of } \\
\text { wine bottle } \\
\text { Screw cap: } 0.00034 \% \text { of } \\
\text { wine bottles }\end{array}$ \\
\hline
\end{tabular}




\section{Discussion and Conclusions}

\subsection{Achievements}

This study provides a better understanding of the global environmental profile of bottled wine considering the different closures used and taking into account the loss rates induced by each closure system.

The main conclusions of the study are as follows:

1. The different closures and associated wine losses represent less than $5 \%$ of the total life cycle impact of bottled wine. The recently published article by Point [14] confirms that the cork stopper contribution to the total bottled wine system represents between $0.4 \%$ and $5 \%$. Impacts related to bottled wine are composed of a several dozens of processes (Point 2008) that contribute to the global impact. While recognizing that the closure impacts are only one element of the overall system, it is only by optimizing the thousands of products and product parts that we are using in our everyday lives that we can move towards sustainability. Reducing closure-related impact represents an easily implementable impact reduction opportunity. Other system parts should also be considered (e.g., bottle production, consumer transport) for further impact reduction opportunities.

2. The wine loss rate resulting from the type of closure and its specific properties is a key parameter to consider when assessing the impact of different wine closures and can result (especially for cork stoppers) in a higher impact than the closure itself. The reduction of wine closures impacts demonstrates the trade-off between the impact of closure and the associated losses.

3. In the case of a cork stopper, the impact of wine loss is larger than the impact of the cork stopper production itself for all examined life cycle impact categories.

4. When the impact of wine loss is considered in addition to the impact of the closure itself, the cork stopper has a higher environmental impact score than the screw cap in all impact categories, provided the effective loss rate of cork stoppers is higher than $1.2 \%$.

In general, LCAs of packaged food consider the following:

- The functional unit used as a reference to estimate the environmental impacts of packaged food should represent an equivalent function among all types of packaging and thus must consider the different associated loss rates.

\subsection{Limitations}

The main limitations of this study include the loss rate estimation and the calculation for the impact of wine production.

Loss rate estimation: the estimated wine loss rates presented in this study are based on (1) expert opinions (i.e., not empirically measured) that reflect their perceived judgment on the percentage of bottled wine that reaches a consumer with an altered taste for each of the closures systems and (2) a sensitivity study on the influence of the consumer behavior. 
Impact of wine production calculation: water use and solid waste generation may also be relevant impact indicators as they were reported in the Corticeira study. These indicators were analyzed for this study, but due to inconsistencies in reporting in the original study as well as in the studies reviewed on the impact of wine production, they are not reported here. Whilst the results for the impact of wine production reflect the state-of-the-art in life cycle assessment, the different environmental indicators are not equally covered in terms of sources, system boundaries and life cycle impact assessment methods used. Most observations and conclusions are based on-and are therefore mainly valid for-global warming and use of non-renewable energy resources, which are the most widely covered in the wine production impact assessment literature.

\subsection{Further Needs}

To address these limitations, the following areas were identified for further exploration:

- The estimation of wine taste alteration rates induced by the cork stoppers and screw caps can be refined in future studies by sampling wines and studying their individual taste alteration rate according to key parameters, such as the type of wine, closure or cap quality, and storage conditions.

- A comprehensive survey on consumer behavior once an altered taste has been identified is needed to better quantify replacement rates and to examine which fraction of the wine is still reused for alternative purposes such as cooking.

- Several differences linked to closure functionality or closure and bottle characteristics (e.g., the additional amount of glass which is needed to accommodate a cork stopper inside the bottle) need to be analyzed and incorporated in further studies.

- The results shown in Figure 6 indicate that there is an opportunity to further improve the environmental performance of other components such as the glass bottle itself, the consumer purchasing trip, vineyard operations, winery processing and transportation, before focusing further on the wine closure system.

- In order to derive conclusions regarding the environmental superiority of closure systems that could be used in a comparative assertion, a comprehensive and full life cycle impact assessment of all indicators (midpoint and endpoint level) including the full functional equivalence must be carried out.

Regarding these limitations and needs, the present study primarily shows the clear importance of accounting for losses in packaging studies for which the impact of the content is much higher than the packaging itself. This study is not intended to be used for comparative assertions.

This study exemplifies the importance of considering the full implication of different components on overall product functionality to draw conclusions regarding environmental preferences. Sustainability in product design, branding and marketing can only be achieved through a fair and comprehensive product assessment. This conclusion is not only applicable for the food and beverage industry, but also to numerous other sectors of the economy such as the electronics industry where the reject or fail rate in the quality control step of electronic component production and resulting losses can be significant [37]. 


\section{Acknowledgements}

This study has been supported by the European Aluminium Foil Association (E.A.F.A.). The authors would like to thank Christian Bauer of E.A.F.A., Cyril Barioz of Amcor and Gerald Rebitzer of Amcor, for their valuable inputs.

\section{References}

1. Point, E.V. Life cycle environmental impacts of wine production and consumption in Nova Scotia, Canada. Master Thesis, Dalhousie University, Halifax, Nova Scotia, Canada, 2008.

2. Aranda, A.; Zabalza, I.; Scarpellini, S. Economic and Environmental Analysis of the Wine Bottle Production in Spain by Means of Life Cycle Assessment; Indersience: Geneva, Switzerland, 2005.

3. Ardente, F.; Beccali, G.; Cellura, M.; Marvuglia, A. POEMS: A case study of an Italian wine-producing firm. Environ. Manage. 2006, 38, 350-364.

4. Colman, T.; Paster, P. Red, White and "Green": The Cost of Carbon in the Global Wine Trade; Working paper; American Association of Wine Economists: New York, NY, USA, 2007.

5. Environmental Product Declaration. Bottled Red Sparkling Wine. Validated Environmental product declaration $\mathrm{N}^{\circ}$ S-P-00109. Available online: http://gryphon.environdec.com /data/files/6/7505/EPD\%20S-P-00109\%20ingl-2008-def.pdf (accessed on 15 October 2012).

6. Environmental Product Declaration, Bottled Organic Red Sparkling Wine. Validated Environmental Product Declaration $\mathrm{N}^{\circ}$ S-P-00119. Available online: http:/gryphon. environdec.com/data/files/6/7521/EPD_Fratello\%20Sole_english\%202008-def.pdf (accessed on 15 October 2012).

7. Niccolucci, V.; Galli, A.; Kitzes, J.; Pulselli, R.M.; Borsa, S.; Marchettini, N. Ecological footprint analysis applied to the production of two Italian wines. Agr. Ecosyst. Environ. 2008, 128, 162-166.

8. Pizzigallo, A.C.I.; Granai, C.; Borsa, S. The joint use of LCA and emergy evaluation for the analysis of two Italian wine farms. J. Environ. Manage. 2008, 86, 396-406.

9. Institut Français de la Vigne et du Vin. Bilan carbone: de la vigne a la bouteille. 2007. Presentation. Available online: http://www.vignevin-sudouest.com/publications/itv-colloque/ documents/COLLOQUE_bilan-carbone-vigne-bouteille.pdf (accessed on 15 October 2012).

10. Gonzalez, A.; Klimchuk, A.; Martin, M. Life Cycle Assessment of Wine Production Process: Finding Relevant Process Efficiency and Comparison with Eco-Wine Production; Report; Royal Institute of Technology: Stockholm, Sweden, 2006.

11. Pattara, C.; Raggi, A.; Cichelli, A. Life cycle assessment and carbon footprint in the wine supply-chain. Environ. Manage. 2012, 49, 1247-1258.

12. Gazulla, C.; Raugei, M.; Fullana-i-Palmer, P. Taking a life cycle look at crianza wine production in Spain: Where are the bottlenecks? Int. J. Life. Cycle. Ass. 2010, 15, 330-337.

13. Bosco, S.; Di Bene, C.; Galli, M.; Remorini, D.; Massai, R.; Bonari, E. Greenhouse gas emissions in the agricultural phase of wine production in the Maremma rural district in Tuscany, Italy. Ital. J. Agron. 2011, 6, 93-100. 
14. Point, E.; Tyedmers, P.; Naugler, C. Life cycle environmental impacts of wine production and consumption in Nova Scotia, Canada. J. Clean. Prod. 2012, 27, 11-20.

15. Vázquez-Rowe, I.; Villanueva-Rey, P.; Moreira, M.T.; Feijoo, G. Environmental analysis of Ribeiro wine from a timeline perspective: Harvest year matters when reporting environmental impacts. J. Environ. Manage. 2012, 98, 73-83.

16. WWF. Cork Screwed? Environmental and Economic Impacts of the Cork Stoppers Market; Report; WWF: Rome, Italy, 2006.

17. Corticeira Amorim. Evaluation of the Environmental Impacts of Cork Stoppers versus Aluminium and Plastic Closures; Final Report; Corticeira Amorim: Mozelos, Portugal, 2008.

18. Boudaoud, N.; Eveleigh, L.; Ruledge, D. Reconnaissance des Arômes et Nez Électronique. Ingénierie Analytique pour la Qualité des Aliments; Report; Institut National de Recherche en Agronomie (INRA): Versailles, France, 2003.

19. Marin, A.; Jorgensen, E.; Kennedy, J.; Ferrier, J. Effects of bottle closure type on consumer perceptions of wine quality. Am. J. Enol. Viticult. 2007, 58, 182-191.

20. Forum oenologie. Available online: http://www.oenologie.fr/ (accessed on 15 October 2012).

21. European Commission, Joint Research Center, Institute for Environment and Sustainability. International Reference Life Cycle Data System (ILCD) Handbook-Framework and Requirements for Life Cycle Impact Assessment Models and Indicators; Publications Office of the European Union: Luxembourg, Luxembourg, 2010.

22. Riboulet, J.-M. Goût de bouchon: Le point sur les origines et les recherches. Rev. Oenolog. 2003, $53,41-43$.

23. Moreau, M. Les moisissures des bouchons. Acad. Agric. Fr. C. R. 1978, 64, 842-849.

24. Davis, C.; Fleet, G.; Lee, T. The microflora of wine cork. Aust.Grape Wine 1981, 208, $42-44$.

25. Chatonnet, P. Etude de l'Australian Wine Research Institute sur les caractéristiques physico-mécaniques de différents obturateurs et la modification de la composition d'un vin blanc après 18 mois de conservation. Rev. Oenolog. 2002, 29, 11-16.

26. Lumia, G.; Perre, C. Les fluides supercritiques, une innovation au service du liège, Partie 1/2. Rev. Oenolog. 2005, 32, 12-15.

27. Lumia, G.; Aracil, J.M. Les fluides supercritiques, une innovation au service du liège, Partie $2 / 2$. Rev. Oenolog. 2006, 33, 13-16.

28. Descout, J. Evolution des connaissances sur le bouchage en liège des vins, les bouchons composites. Rev. Oenolog. 2008, 35, 28-31.

29. MIS Trend. Etude sur le Marché du Vin en Suisse: Notoriété, Habitudes de Consommation et d'Achat, Image; Report; MIS Trend: Lausanne, Switzerland, 2008. Available online: http://www.mistrend.ch/articles/La_viticulture_suisse.pdf/ (accessed on 15 October 2012).

30. Struijs, J. SimpleTreat 3.0: A Model to Predict the Distribution and Elimination of Chemicals by Sewage Treatment Plants; Report; National Institute of Public Health and the Environment: Bilthoven, The Netherlands, 1996.

31. VROM. Protocol 8136 Afvalwater, t.b.v NIR 2008 uitgave maart 2008 6B: CH4 en N2O uit Afvalwater; Directie Klimaatverandering en Industrie: The Hague, the Netherlands, 2008.

32. Daelman, M.; van Voorthuizen, E.; van Dongen, U.; Volcke, E.; van Loosdrecht, M. Methane emission during municipal wastewater treatment. Water Res. 2012, 46, 3657-3670. 
33. IPCC. Contribution of Working Group I to the Fourth Assessment Report of the Intergovernmental Panel on Climate Change; Cambridge University Press: Cambridge, UK, 2007.

34. Humbert, S.; Margni, M.; Jolliet, O. IMPACT 2002+: Methodology Description, Draft for Version 2.1, unpublished work.

(C) 2012 by the authors; licensee MDPI, Basel, Switzerland. This article is an open access article distributed under the terms and conditions of the Creative Commons Attribution license (http://creativecommons.org/licenses/by/3.0/).

\section{Supporting Information}

\section{S1. Literature Review on Wine Environmental Impacts}

The environmental impact of wine has been evaluated using the following references.

Table S1. Details of the literature review on wine environmental impacts.

\begin{tabular}{|c|c|c|c|c|c|c|}
\hline Author & Year & Scope & Functional unit & $\begin{array}{c}\text { Global } \\
\text { warming } \\
\text { (kg/function } \\
\text { al unit) }\end{array}$ & $\begin{array}{c}\text { Non- } \\
\text { renewable } \\
\text { energy use } \\
\text { (MJ/function } \\
\text { al unit) }\end{array}$ & Others \\
\hline
\end{tabular}

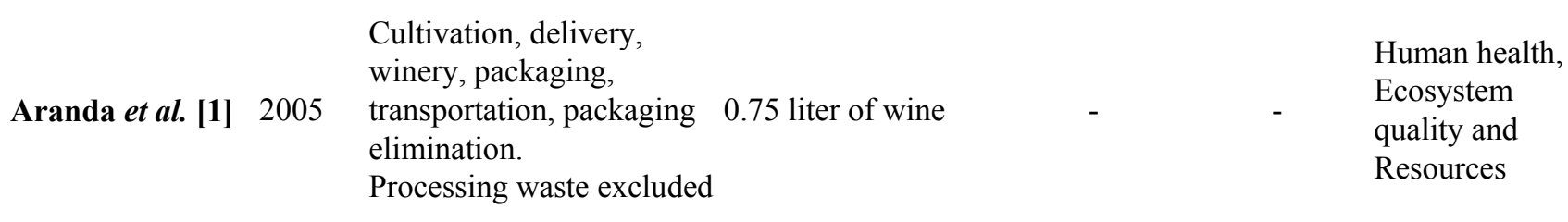

Cultivation, delivery,

$\begin{array}{lllll}\text { Ardente } \text { et al. [2] } 2006 & \begin{array}{l}\text { winery, packaging, } \\ \text { transport (to retail, truck in } 0.75 \text { liter of red wine }\end{array} & 1.6 & 28.1 & \begin{array}{l}\text { Solid waste } \\ \text { generated }\end{array} \\ & \text { EU, ship overseas). } \\ & \text { Elimination not included }\end{array}$

Elimination not included

$\begin{array}{llll}\text { Colman and } & 2007 & \begin{array}{l}\text { Vineyard, winery, } \\ \text { packaging and distribution } 0.75 \text { liter of wine } \\ \text { in US }\end{array} & 3.35\end{array}$

\begin{tabular}{|c|c|c|c|c|c|c|}
\hline $\begin{array}{l}\text { EPD } \\
\text { conventional [4] }\end{array}$ & 2008 & $\begin{array}{l}\text { Cultivation, delivery, } \\
\text { winery, packaging, } \\
\text { transportation, packaging } \\
\text { elimination. } \\
\text { Production waste excluded }\end{array}$ & $\begin{array}{l}1 \text { liter of Grasparossa } \\
\text { Righi, sparkling red } \\
\text { wine }\end{array}$ & 2.24 & - & $\begin{array}{l}\text { Ozone depletion, } \\
\text { Acidification, } \\
\text { Eutrophication, } \\
\text { Photochemical } \\
\text { Photo-oxidant } \\
\text { formation }\end{array}$ \\
\hline
\end{tabular}


Table S1. Cont.

\begin{tabular}{|c|c|c|c|c|c|c|}
\hline Author & Year & Scope & Functional unit & $\begin{array}{c}\text { Global } \\
\text { warming } \\
\text { (kg/function } \\
\text { al unit) }\end{array}$ & $\begin{array}{c}\text { Non- } \\
\text { renewable } \\
\text { energy use } \\
\text { (MJ/function } \\
\text { al unit) }\end{array}$ & Others \\
\hline
\end{tabular}

\begin{tabular}{|c|c|c|c|c|c|}
\hline EPD organic [5] & $\begin{array}{l}\text { Cultivation, delivery, } \\
\text { winery, packaging, } \\
\text { transportation, packaging } \\
\text { elimination. } \\
\text { Production waste excluded }\end{array}$ & $\begin{array}{l}1 \text { liter of organic } \\
\text { lambrusco } \\
\text { Grasparossa "Fratello } \\
\text { Sole", } \\
\text { sparkling red wine }\end{array}$ & 1.35 & - & $\begin{array}{l}\text { Ozone depletion, } \\
\text { Acidification, } \\
\text { Eutrophication, } \\
\text { Photo-chemical } \\
\text { oxidant formation }\end{array}$ \\
\hline Gonzalez et al. [6] 2006 & $\begin{array}{l}\text { Cultivation, delivery, } \\
\text { winery, packaging, } \\
\text { transportation, packaging } \\
\text { elimination }\end{array}$ & $\begin{array}{l}1 \text { liter of wine (glass } \\
\text { bottle, cork stopper) }\end{array}$ & - & - & $\begin{array}{l}\text { Graphic } \\
\text { normalized } \\
\text { midpoints results } \\
\text { in point } \\
\end{array}$ \\
\hline $\begin{array}{l}\text { Institut Français } \\
\text { de la Vigne et du } 2007 \\
\text { Vin [7] }\end{array}$ & $\begin{array}{l}\text { Cultivation, delivery, } \\
\text { winery, packaging, } \\
\text { transportation, packaging } \\
\text { elimination }\end{array}$ & 1 bottle unit & 1.24 & - & - \\
\hline
\end{tabular}

\begin{tabular}{|c|c|c|c|c|c|c|}
\hline $\begin{array}{l}\text { Niccolucci } \\
\text { et al. }[8]\end{array}$ & 2008 & $\begin{array}{l}\text { Cultivation, delivery, } \\
\text { winery, packaging }\end{array}$ & $\begin{array}{l}1 \text { ton of wine } \\
\text { produced; } 1 \text { bottle of } \\
\text { wine, } 1 \text { global } \\
\text { hectare equivalent } \\
\text { (gha) of a vineyard }\end{array}$ & - & - & $\begin{array}{l}\text { Ecological } \\
\text { footprint }\end{array}$ \\
\hline
\end{tabular}

\begin{tabular}{|c|c|c|c|c|c|c|}
\hline \multirow{3}{*}{$\begin{array}{l}\text { Pizzigallo } \\
\text { et al. [9] }\end{array}$} & \multirow{3}{*}{2006} & \multirow{3}{*}{$\begin{array}{l}\text { Cultivation, delivery, } \\
\text { winery, packaging, } \\
\text { transportation, packaging } \\
\text { elimination }\end{array}$} & \multirow{3}{*}{1 ton of wine } & \multirow{3}{*}{-} & \multirow{3}{*}{-} & $\begin{array}{l}3.08 \mathrm{E}+15 \mathrm{sej} \\
\text { organic farm }\end{array}$ \\
\hline & & & & & & $\begin{array}{l}4.17 \mathrm{E}+15 \text { sej } \\
\text { semi-industrial } \\
\text { farm }\end{array}$ \\
\hline & & & & & & $\begin{array}{l}\text { sej }=\text { solar } \\
\text { emjoules }\end{array}$ \\
\hline Point [10] & 2008 & $\begin{array}{l}\text { Cultivation, delivery, } \\
\text { winery, packaging, } \\
\text { transportation (to retail, } \\
\text { consumer), refrigeration, } \\
\text { packaging elimination. } \\
\text { Infrastructure not included }\end{array}$ & 0.75 liter of wine & 3.95 & 57.8 & $\begin{array}{l}\text { Abiotic resources } \\
\text { depletion, } \\
\text { Acidification } \\
\text { potential, } \\
\text { Eutrophication, } \\
\text { Ozone depletion, } \\
\text { Aquatic } \\
\text { ecotoxicity, } \\
\text { Terrestrial } \\
\text { ecotoxicity, } \\
\text { Photo--oxidant } \\
\text { formation }\end{array}$ \\
\hline
\end{tabular}

The impacts presented in Figures S1 to S7 and used for impact results in the study are an average of the values found in the selected studies. For each indicator, a set of references presenting relevant results is selected. 
In order to determine the average impact of bottled wine in a consistent manner across the different studies selected, the functional unit $750 \mathrm{~mL}$ drinkable wine was used to recalculate figures for all studies, using a linear mass allocation. Closure and losses impact are not included in the graphs to focus on the bottled wine impact.

\section{S1.1. Global Warming Score}

The global warming score for wine is calculated based on the average of six references.

These references include the following life cycle steps: vineyard operations, winery operations, distribution and packaging waste treatment. The use phase was added using data from Point [10], which is the only study that calculated the impacts of this life cycle stage.

Figure S1 compares the sum of these two calculated values with the individual results of the different studies.

Figure S1. Average global warming score for the life cycle of bottled wine.

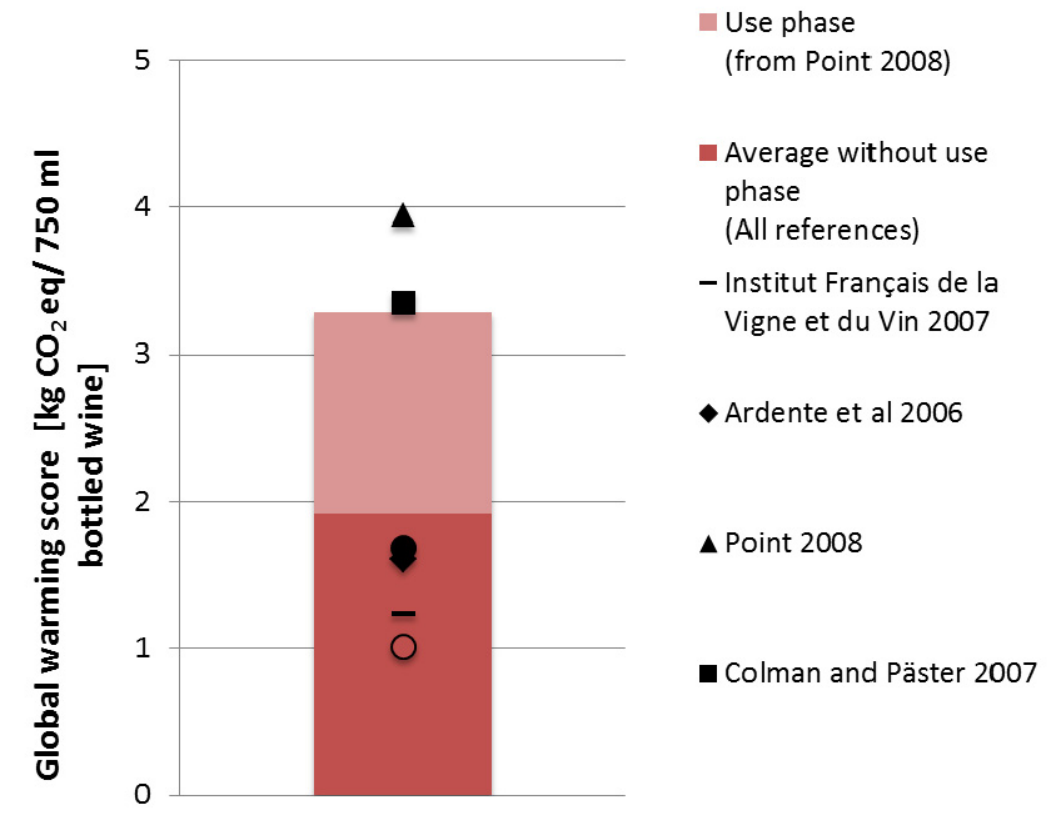

The average of global warming score is $3.3 \mathrm{~kg} \mathrm{CO}_{2}$ eq per typical $750 \mathrm{~mL}$ of bottled wine, including the use phase.

Overall, it appears that the global warming score for bottled wine ranges between 1 and $4 \mathrm{~kg} \mathrm{CO} \mathrm{CO}_{2}$. Point [10] calculates a higher value because the study takes the following complementary elements into account: customer purchasing and refrigeration at home. Colman and Päster [3] also obtain higher results than the average. Indeed, this analysis considers transoceanic ship or air transport from the production location to the consumption site.

Figure S2 presents the global warming score according to the results of Point [10], which is the only reference providing details of the consumption phase of bottled wine. 
Figure S2. Global warming score for the different life cycle stages of bottled wine.

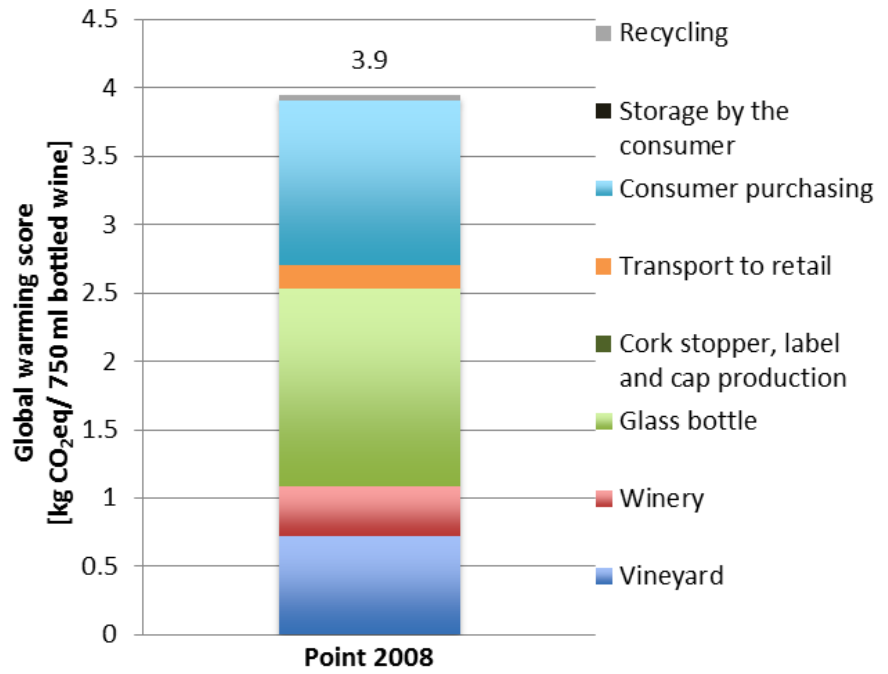

The global warming score is dominated by the packaging (glass bottle, 37\%) and consumer purchasing (30\%). The weight of glass bottle is assumed as $540 \mathrm{~g}$. In Point [10], a sensitivity analysis is conducted considering a scenario with a lighter bottle $(380 \mathrm{~g})$ and the global warming score is reduced by $12 \%$. The vineyard and winery also represent important stages in the life cycle of wine production (18\% and $9 \%$, respectively). The cork stopper, the label and the cap together represent only $0.05 \%$ of the global warming score.

\section{S1.2. Non-Renewable Primary Energy Use}

The non-renewable primary energy use of wine is calculated based on the average of four references that consider the vineyard operations, winery operations, distribution and packaging disposal. The use phase is calculated using Point [10]. Figure S3 presents the sum of these two computations compared with the non-renewable energy use calculated by the four different references.

Figure S3. Average primary non-renewable energy use of the life cycle of bottled wine.

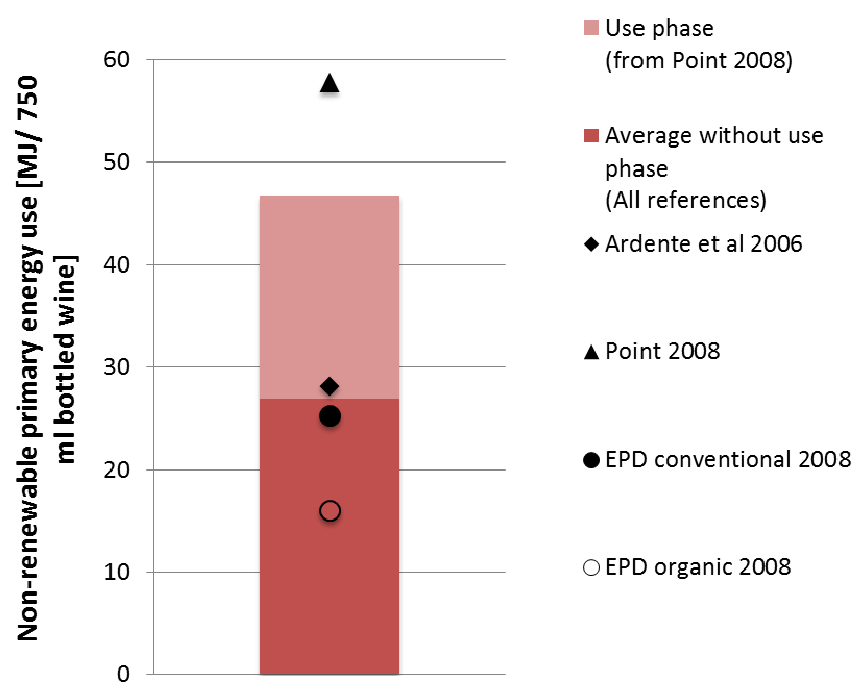


The average for primary non-renewable energy use, including the impact of the use stage as assessed by Point [10], is $47 \mathrm{MJ}$ per $750 \mathrm{~mL}$ of bottled wine.

Figure S4 presents the details of cumulative non-renewable energy demand according to the results of Point [10].

Figure S4. Use of non-renewable primary energy for the different life cycle stages of bottled wine.

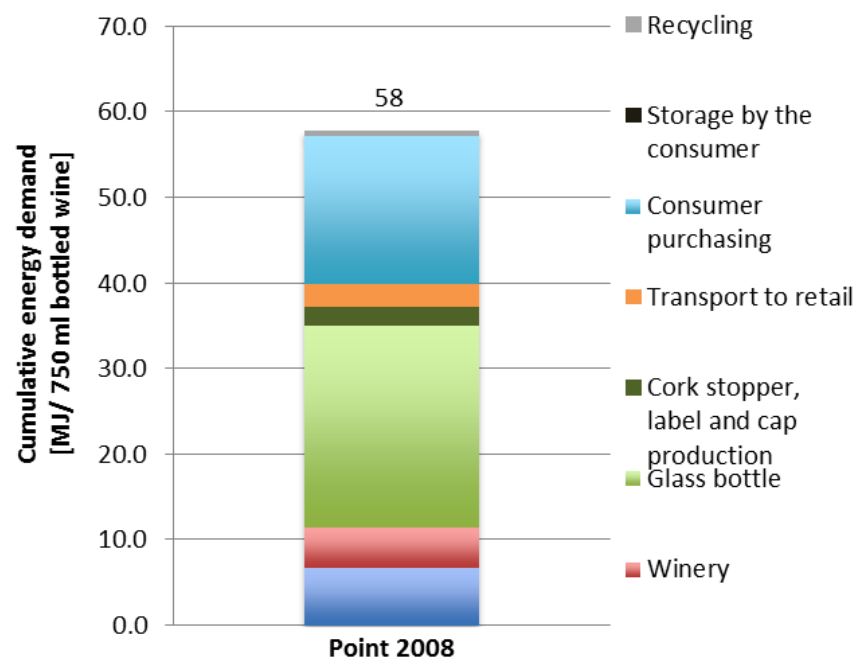

As with the global warming score, it appears that the stages that dominate the life cycle impacts are the bottled wine production and consumer purchasing. However the proportions are slightly different; the glass bottle represents $45 \%$ of the non-renewable energy use (including $4 \%$ for the cork stopper and the label production), whereas consumer purchasing represents $30 \%$, the vineyard operations represent $12 \%$ and the winery operations represent $8 \%$ of the non-renewable energy use. The cork stopper, the label and the cap together represent only $4 \%$ of the non-renewable energy used.

\section{S1.3. Contribution to Atmospheric Acidification}

The potential of atmospheric acidification of wine production is calculated based on the average of three of the selected references considering the vineyard operations, winery operations, distribution and packaging disposal. The impacts of the use phase are calculated per Point [10]. Figure S5 compares the sum of these two calculations with the results of each of the three references. 
Figure S5. Average atmospheric acidification potential for the life cycle of bottled wine.

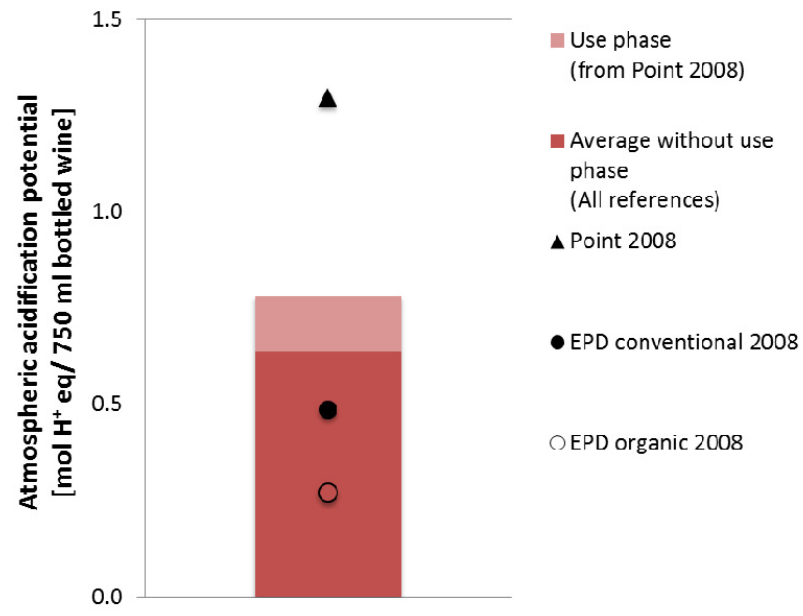

The average contribution to atmospheric acidification is $0.78 \mathrm{~mol} \mathrm{H}^{+}$eq $\left(0.78 \mathrm{~g} \mathrm{H}^{+}\right.$eq $)$per $750 \mathrm{~mL}$ of bottled wine.

\section{S1.4. Contribution to the Formation of Photo-Oxidant}

The photo-oxidant formation potential of wine is evaluated based on the average of three references that consider the vineyard operations, winery operations, distribution and packaging disposal. The impact of the use stage is calculated per Point [10]. Figure S6 presents the sum of these two calculations and the individual results of each study.

Figure S6. Average photo-oxidant formation potential the life cycle of bottled wine.

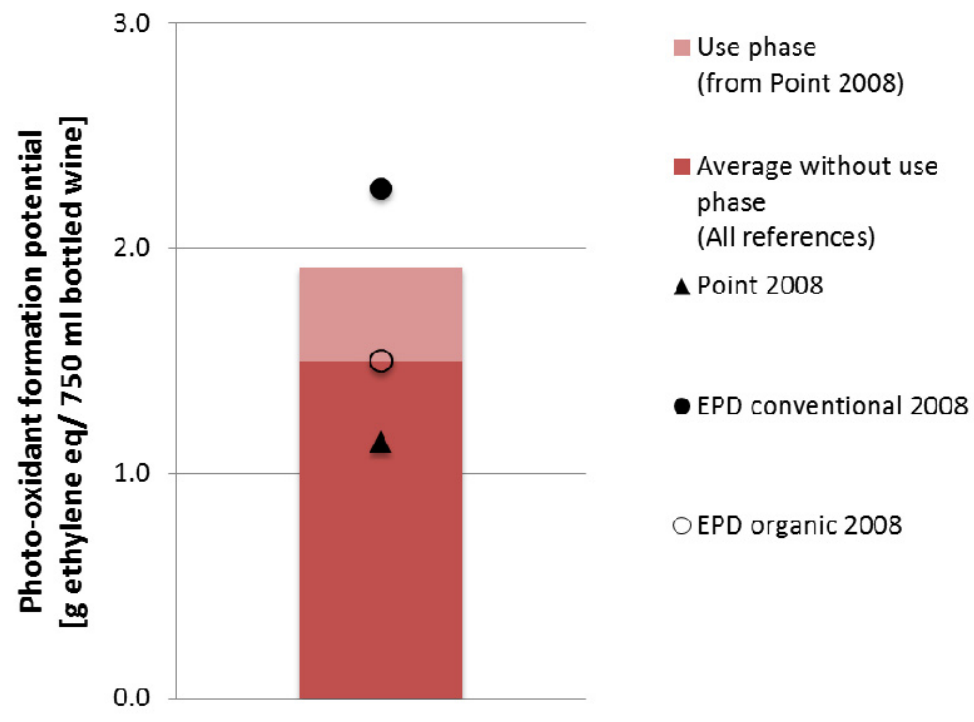

The average photo-oxidant formation potential is $1.9 \mathrm{~g}$ ethylene eq per $750 \mathrm{~mL}$ of bottled wine.

\section{S1.5. Contribution to the Eutrophication of Surface Water}

The eutrophication potential of wine production is calculated based on the average of three selected 
references that consider the following life cycle steps: vineyard operations, winery operations, distribution and packaging disposal. The impact of the use stage is calculated per Point [10]. Figure S7 presents the sum of these two calculations and the individual results calculated by the three different references consulted.

Figure S7. Average eutrophication potential for the life cycle of bottled wine.

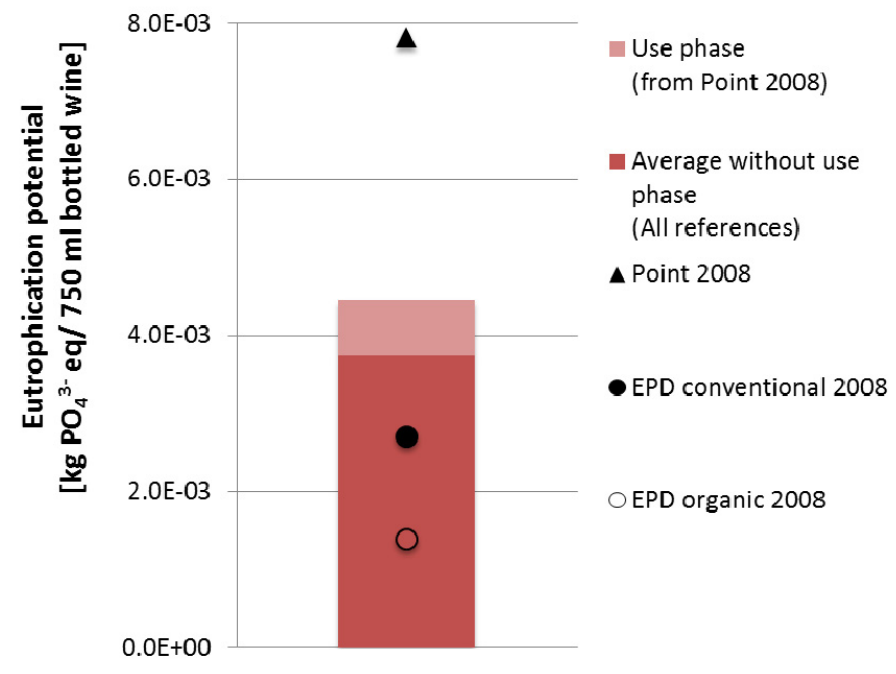

The average eutrophication potential is $4.5 \mathrm{E}-3 \mathrm{~kg} \mathrm{PO}_{4}{ }^{3-}$ eq per $750 \mathrm{~mL}$ of bottled wine.

\section{S2. References for Wine Taste Alteration Rate Estimation}

The wine taste alteration rates induced by the use of cork and aluminum-based (screw cap) closures were determined based on interviews with wine producers, representatives from the main institutes working in this field, specialized laboratories and professional bottlers in May 2012. Wine taste alteration rates associated with cork closures are estimated from these interviews as follows:

- French federation of cork syndicates (Jean-Marie Aracil): 0.7\%

- Australian Wine Research Institute (AWRI): 2-5.5\%

- Vectoeur, a scientific laboratory for wine: $4 \%$

- Oeneo, wine closure producer: $5 \%$

- Korked, wine closure producer (Giovanni Capello): 3-5\%

- University of Applied Sciences Changins (Christian Maurer): 2-4\%

- University of Bordeaux (Pierre-Louis Teissedre): 1-2\%

Literature data on cork closures has also been collected:

- Boudaoud et al. [11]: 2-5.5\%

- Marin et al. [12]: 4.9\%

Information provided for screw caps is as follows:

- Excell laboratory for closure quality control (Pascal Chatonnet): 10 times less than cork stoppers 
- University of Applied Sciences Changins (Christian Maurer): minimum 5 times less than cork stoppers

Based on the previously mentioned sources and his expert judgment on their respective quality and relevance, the wine expert Richard Pfister consulted in this study estimated the following wine taste alteration rates, the low values of $2 \%$ and $5 \%$ corresponding to the medians of the limits provided above by the different experts and literature sources:

- Cork stoppers: $2-5 \%$

- Screw caps: 5-10 times less than cork stoppers, with the most probable value selected as 7.5 times less $(0.3-0.7 \%)$

\section{S3. Estimation of the Life Cycle Stage at which the Failure Originated}

Table S2 summarizes the estimated taste alteration rates at the consumer for cork stoppers and screw caps, as well as the estimated stage of the life cycle where the failure originated as determined by expert judgment.

Table S2. Estimated taste alteration rates at the consumer level for the two closure systems, and the life cycle stage at which the failure originated.

Estimated fraction of wine taste alteration at

Closure type consumer

\begin{tabular}{|c|c|c|c|}
\hline & & Cork stopper & Screw cap \\
\hline \multirow{10}{*}{$\begin{array}{l}\text { Stage at which the } \\
\text { failure occurs and results } \\
\text { in an altered taste or } \\
\text { smell }\end{array}$} & \multirow[b]{2}{*}{ Closure manufacture } & $4 / 10$ & $2 / 10$ \\
\hline & & $\begin{array}{c}\text { Poor sorting, poor raw } \\
\text { material quality }\end{array}$ & Inappropriate liner choice \\
\hline & \multirow{2}{*}{ Delivery } & $1 / 10$ & $1 / 10$ \\
\hline & & \multicolumn{2}{|c|}{ Poor transport and storing conditions } \\
\hline & \multirow[b]{2}{*}{ Winery operations } & $2 / 10$ & $5 / 10$ \\
\hline & & \multicolumn{2}{|c|}{$\begin{array}{l}\text { Poor storing of closures, poor calibration of the bottling } \\
\text { machinery }\end{array}$} \\
\hline & \multirow[b]{2}{*}{ Distribution } & $1 / 10$ & $1 / 10$ \\
\hline & & \multicolumn{2}{|c|}{$\begin{array}{l}\text { Transport in inappropriate conditions (such as } \\
\text { inappropriate temperature, sun exposure, humidity, etc.) }\end{array}$} \\
\hline & \multirow[b]{2}{*}{ Consumer } & $2 / 10$ & $1 / 10$ \\
\hline & & \multicolumn{2}{|c|}{$\begin{array}{c}\text { Conservation problem (such as storage over a long } \\
\text { period of time) }\end{array}$} \\
\hline
\end{tabular}




\section{S4. Estimations for the Wine Disposal Model}

\section{S4.1. Calculation of the Initial Carbon Mass}

The parameters used for the amount of carbon disposed are as follows:

$\mathrm{V}_{\text {bottle: }}$ Volume of wine bottle: $750 \mathrm{~mL}$

$p_{\text {ethanol }}$ : Fraction of ethanol in the wine bottle: $10 \%$

$\mathrm{d}_{\text {ethanol }}$ : Ethanol density: $0.789 \mathrm{~g} / \mathrm{mL}$

$\mathrm{Mm}_{\text {carbon: }}$ molar mass of carbon: $12 \mathrm{~g} / \mathrm{mol}$

$\mathrm{Mm}_{\text {ethanol: }}$ molar mass of ethanol: $46 \mathrm{~g} / \mathrm{mol}$

$\mathrm{N}$ : number of carbon atoms per ethanol molecule: 2

$M_{\text {carbon }}=V_{\text {bottle }} \times p_{\text {ethanol }} \times d_{\text {ethanol }} \times \frac{1}{M m_{\text {ethanol }}} \times N \times M m_{\text {carbon }}$

Following this equation, the mass of carbon obtained $\mathrm{M}_{\text {carbon }}$ is $30.9 \mathrm{~g}$ (rounded to $31 \mathrm{~g}$ ).

\section{S4.2. Input and Output Parameters for SimpleTreat 3.1 Model}

The fate of ethanol in the wastewater treatment plant was modeled with the SimpleTreat tool 3.1. Input physical-chemical substance properties and degradation and transformation rates are displayed in Table 1 and obtained output distribution ratios are shown in Table 2. 
Table S3. Input parameters used in Simpletreat 3.1 tool [13].

\begin{tabular}{|c|c|}
\hline \multicolumn{2}{|l|}{ Substance Identification } \\
\hline General name & ethanol \\
\hline CAS no. & $64-17-5$ \\
\hline \multicolumn{2}{|l|}{ Physical-Chemical Substance Properties } \\
\hline Molecular weight & 46.07 g.mol ${ }^{-1}$ \\
\hline Melting point & $-87.84{ }^{\circ} \mathrm{C}$ \\
\hline Vapour pressure at the temperature of the data set & 7.9E+03 Pa \\
\hline Temperature at which vapour pressure was measured & $25^{\circ} \mathrm{C}$ \\
\hline Water solubility at the temperature of the data set & $1.0 \mathrm{E}+06 \mathrm{mg} \cdot \mathrm{L}^{-1}$ \\
\hline Temperature at which solubility was measured & $25{ }^{\circ} \mathrm{C}$ \\
\hline \multirow[t]{2}{*}{ Octanol-water partition coefficient } & 4.9E-01 \\
\hline & - \\
\hline \multirow{2}{*}{ Chemical class for Koc-QSAR } & Alcohols \\
\hline & - \\
\hline Organic carbon-water partition coefficient & $1.58 \mathrm{E}+00$ L.kg-1 \\
\hline \multicolumn{2}{|l|}{ Degradation and Transformation Rates } \\
\hline \multicolumn{2}{|l|}{ Characterization } \\
\hline \multirow{2}{*}{ Biodegradability test result } & readily biodegradable \\
\hline & - \\
\hline Rate constant for degradation in STP & $d-1$ \\
\hline Total rate constant for degradation in surface water at env. temp & $8.0 \mathrm{E}-02 \mathrm{~d}^{-1}$ \\
\hline Total rate constant for degradation in marine water at env. temp & $\mathrm{d}-1$ \\
\hline Total rate constant for degradation in bulk sediment at env. temp & $8.9 \mathrm{E}-03 \mathrm{~d}-1$ \\
\hline Rate constant for degradation in air & $2.1 \mathrm{E}-01 \mathrm{~d}-1$ \\
\hline Total rate constant for degradation in bulk soil at env. temp & $4.0 \mathrm{E}-02 \mathrm{~d}-1$ \\
\hline
\end{tabular}

Table S4. Output distribution ratios for a treatment including primary sedimentation.

\begin{tabular}{lr}
\hline Summary of distribution & \\
\hline to air & 0.1 \\
to water & 12.6 \\
via primary sludge & 0.0 \\
via surplus sludge & 0.0 \\
degraded & 87.3 \\
total & 100.0 \\
\hline
\end{tabular}




\section{S4.3. Calculation of Chemical Oygen Demand/Total Organic Carbon Ratio}

The theoretical oxygen demand (ThOD) and total organic carbon for ethanol were calculated based on the molecular formula as follows:

$$
\mathrm{CH}_{3} \mathrm{CH}_{2} \mathrm{OH}+3 \mathrm{O}_{2} \rightarrow 2 \mathrm{CO}_{2}+3 \mathrm{H}_{2} \mathrm{O}
$$

Theoretical oxygen demand is considered a good estimate for chemical oxygen demand. With these calculation algorithms, the following results were obtained:

Chemical oxygen demand (COD): $2.08 \mathrm{~g} / \mathrm{g}$ ethanol

Total organic carbon (TOC): $0.52 \mathrm{~g} / \mathrm{g}$ ethanol

COD/TOC: 4

\section{S5. Reference Scenario: Uncertainty Analysis Parameters and Results}

For a given impact category, the impact score $\mathrm{S}$, associated to the cork stopper and the screw cap is given as a function of the replacement rate $\left(r_{l}\right)$ and the wine alteration rate for the considered closure system $\left(r_{r}\right)$ as follows:

$$
\begin{aligned}
& S_{\text {cork stopper bottle }}^{\text {total }}=S_{\text {cork stopper }}+r_{r} \cdot r_{\text {l cork stopper }} \cdot S_{\text {wine }} \\
& S_{\text {screw cap bottle }}^{\text {total }}=S_{\text {screw cap }}+r_{r} \cdot r_{l \text { screw cap }} \cdot S_{\text {wine }}
\end{aligned}
$$

where $S_{\text {corkstopper }}$ is the impact score associated with the production of the closure and $S_{\text {wine }}$ is the impact of $750 \mathrm{~mL}$ of wine.

The alteration rate for screw caps is defined as a function of the alteration rate of cork stoppers:

$$
r_{l \text { screwcap }}=r_{\text {l cork stopper }} \cdot y
$$

where $y$ is a multiplication factor.

The uncertainty distributions are defined as follows:

$S_{\text {wine }}$ : triangular distribution specified in Table S5

$r_{\text {lcork stopper }}: 3 \%$ with uniform distribution (minimum: $2 \%$, maximum: $5 \%$ )

$r_{r}: 77 \%$ with triangular distribution (minimum: 50\%, maximum: 100\%)

$S_{\text {cork stopper }}$ : triangular distribution specified in Table S5

$S_{\text {screw cap }}$ : triangular distribution specified in Table S5

$y: 0.13$ times with a triangular distribution (minimum: 0.1 , maximum: 0.2 , which corresponds to the expert estimate that the impact of screw caps is 5-10 less than cork stoppers)

Table S5 shows the distribution of $S_{\text {wine }}, S_{\text {cork stopper }}$ and $S_{\text {screwcap }}$. The uncertainty on the closure impact is based on uncertainty factors (dimensionless) used for the development of ecoinvent v1.1 applied for technosphere inputs and outputs [14]. 
Table S5. Details of the standard deviation calculations.

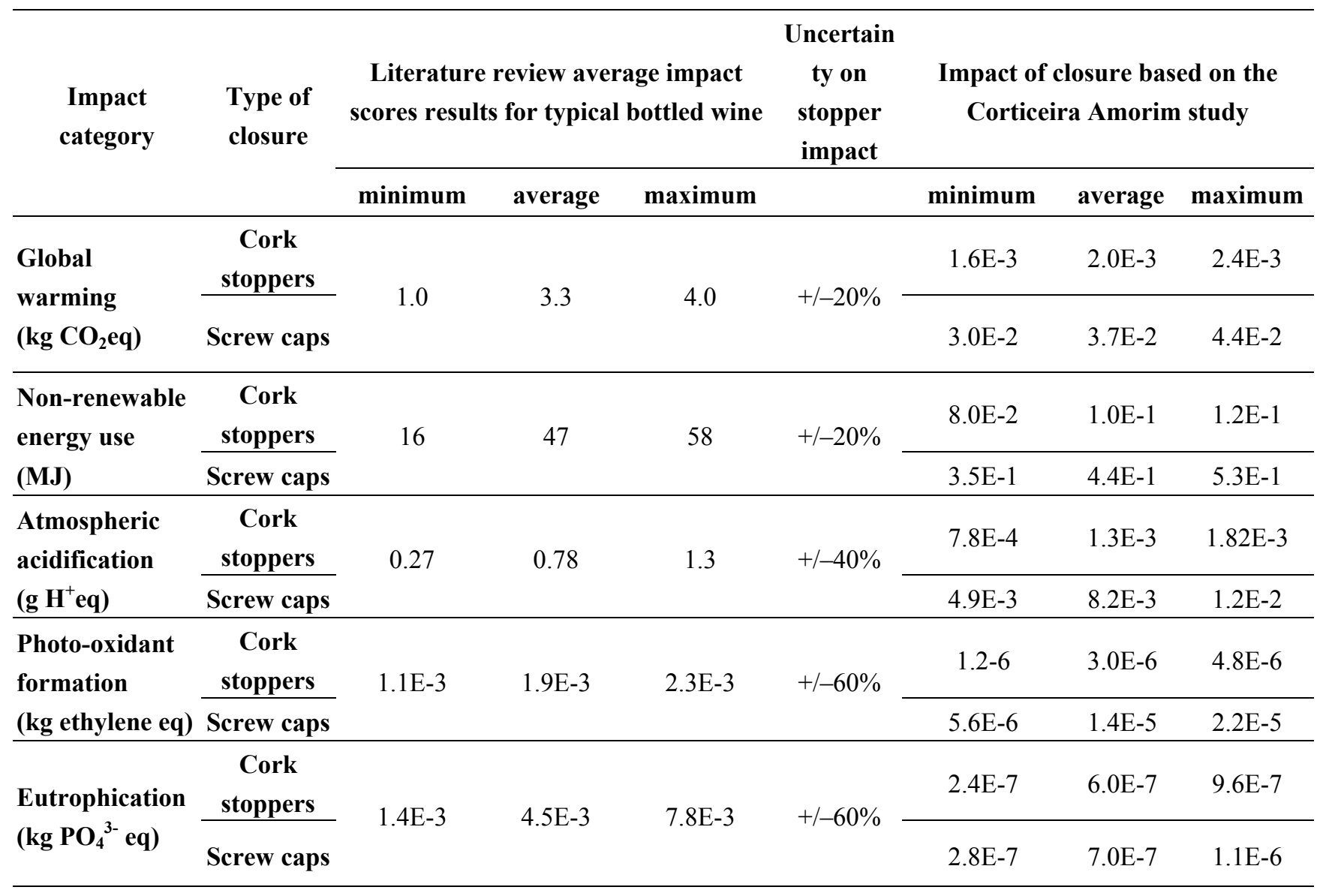

Figure S8 shows the uncertainty analysis on the cork stopper and screw cap systems. 
Figure S8. Monte Carlo analysis with 5000 runs for the cork stopper and screw cap system for the (a) non-renewable energy, (b) atmospheric acidification, (c) photo-oxidant formation and (d) eutrophication impact categories.

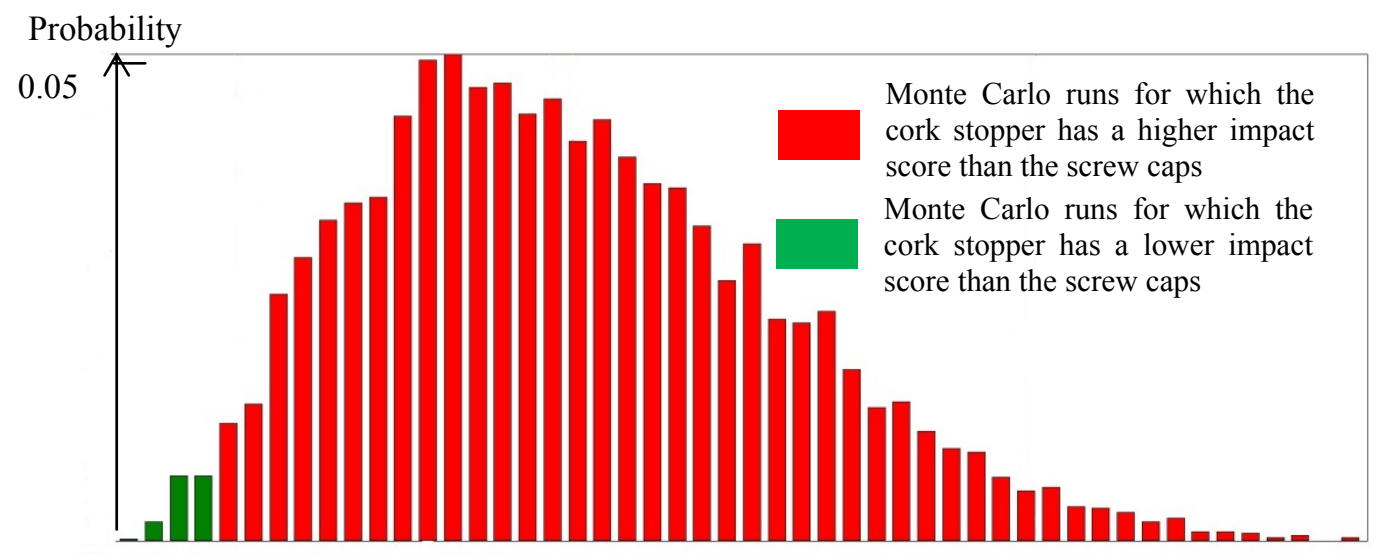

(a)

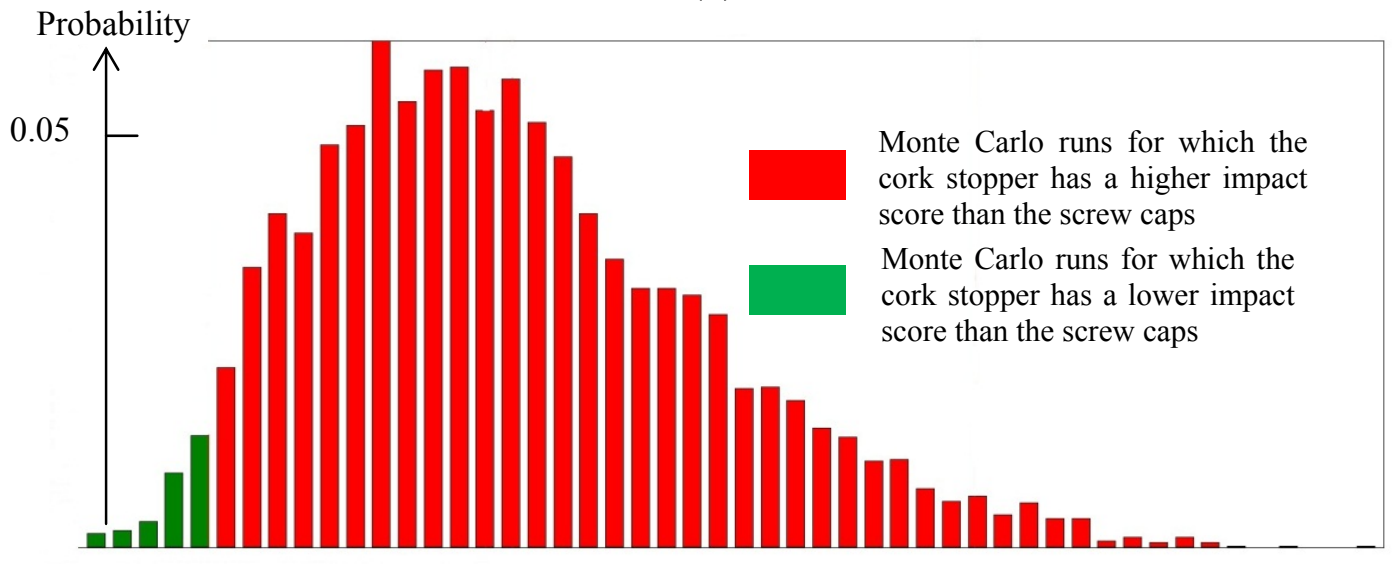

(b)

Probability

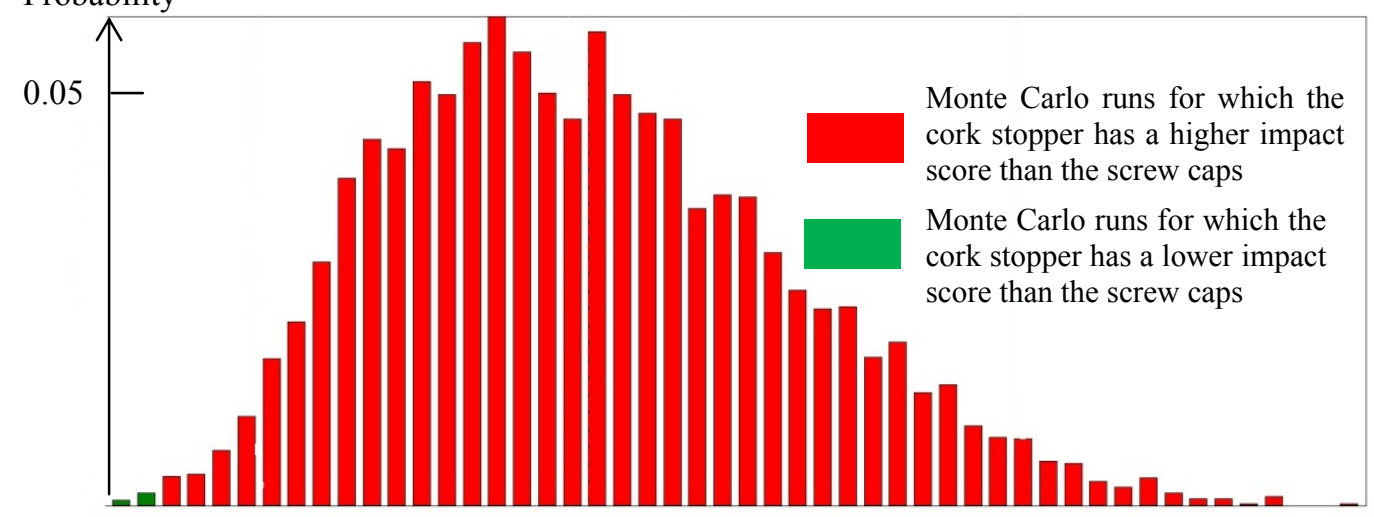

(c) 
Figure S8. Cont.

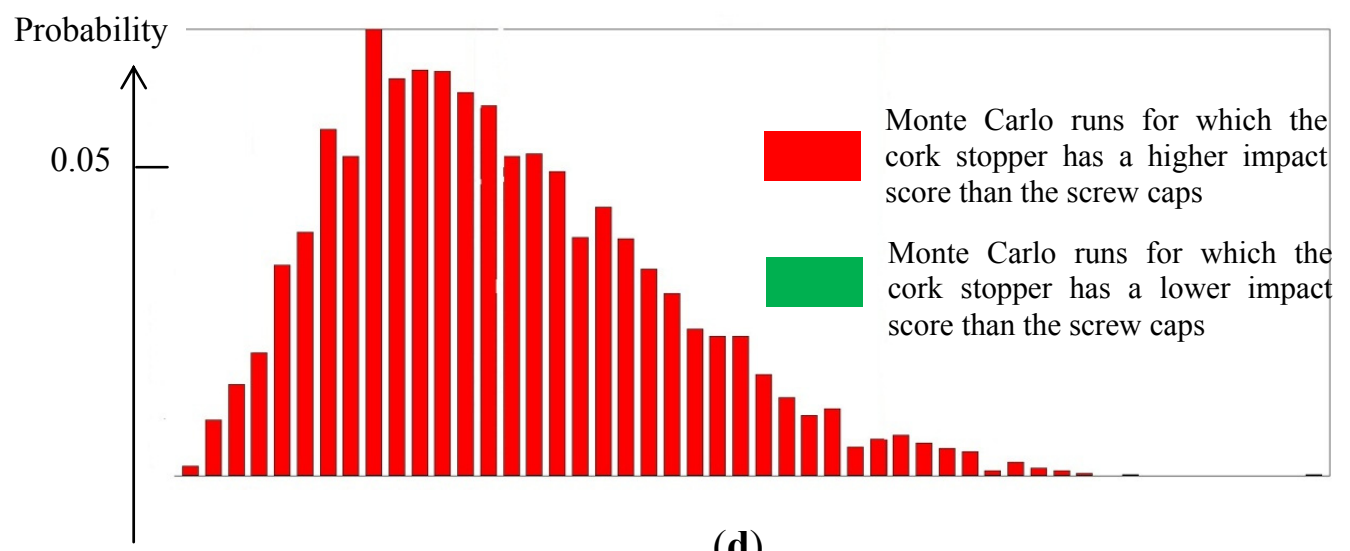

(d)

\section{S6. Sensitivity Analysis: Break-Even Replacement and Effective Loss Rate Determination}

Figure S9 shows the comparison between the cork stopper and the screw cap as a function of the replacement rate, for low ( $2 \%$ for cork stopper, $0.3 \%$ for screw caps), medium ( $3.5 \%$ for cork stopper, $0.5 \%$ for screw caps) and high ( $5 \%$ for cork stopper, $0.7 \%$ for screw caps) wine loss rates at the breakeven point, $S_{\text {cork stopperbottle }}^{\text {total }}\left(r_{r \text { break-even }}\right)=S_{\text {screwcap bottle }}^{\text {total }}\left(r_{r \text { break-even }}\right)$, which is calculated as follows:

$$
r_{r \text { break-even }}=\frac{S_{\text {screw cap }}-S_{\text {scork stopper }}}{\left(r_{l \text { cork stopper }}-r_{l \text { screw cap }}\right) \cdot S_{\text {wine }}}
$$

Figure S9. Impact score of the cork stopper compared to the screw cap as a function of the replacement rate.
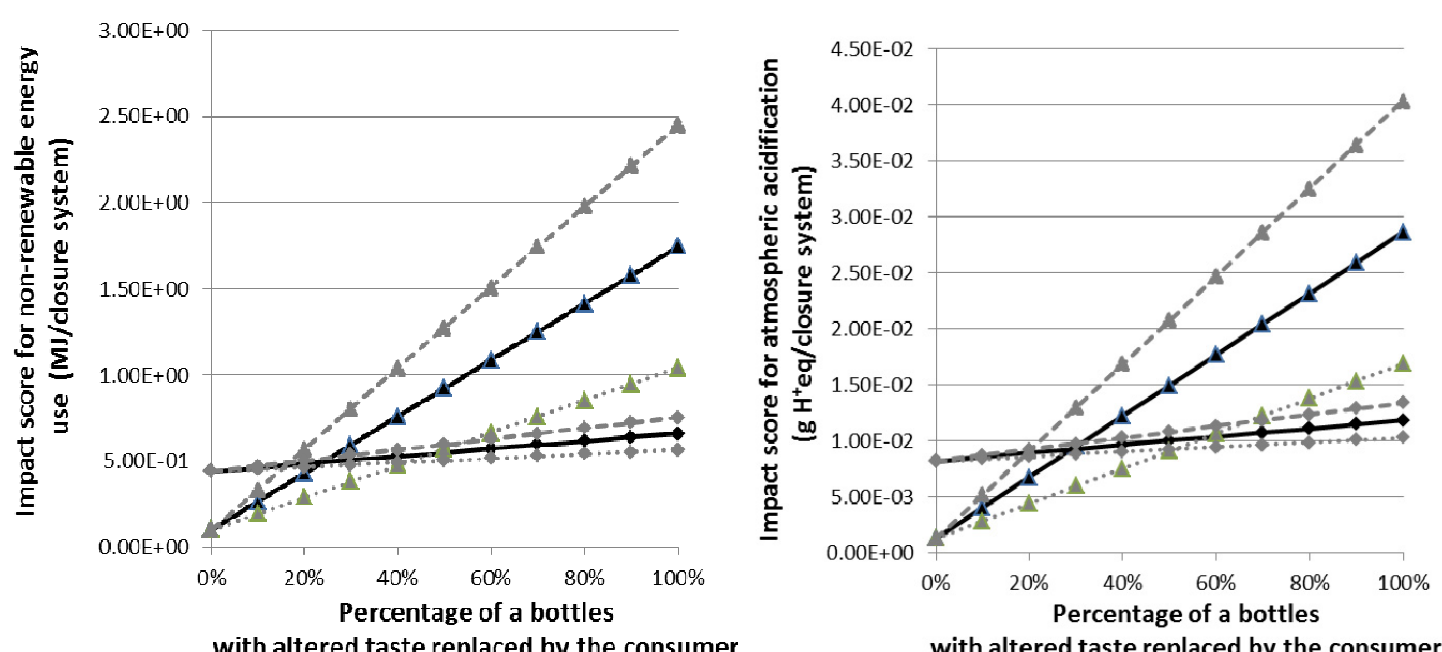
Figure S9. Cont.
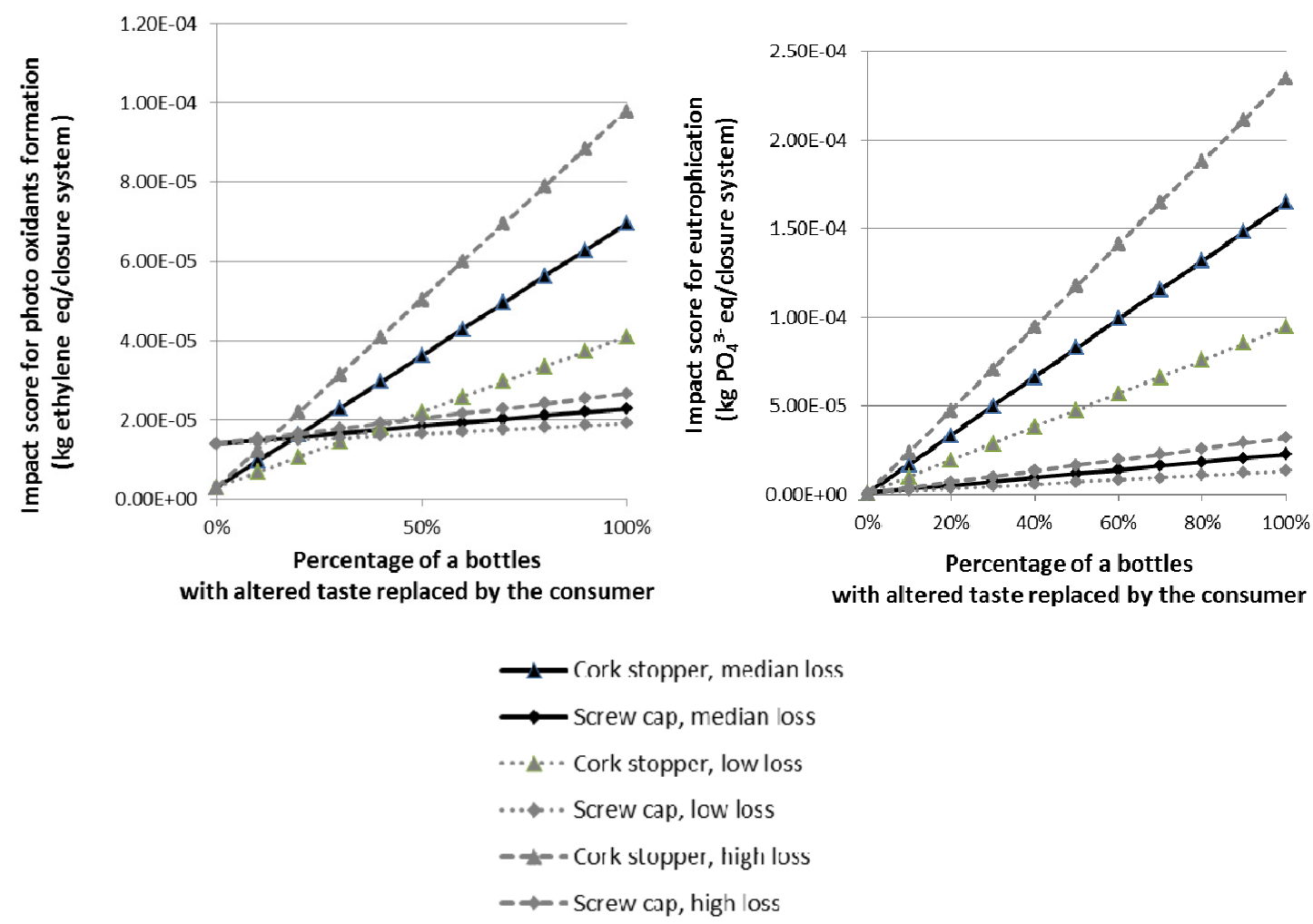

\section{References}

1. Aranda, A.; Zabalza, I.; Scarpellini, S. Economic and Environmental Analysis of the Wine Bottle Production in Spain by Means of Life Cycle Assessment; Indersience: Geneva, Switzerland, 2005.

2. Ardente, F.; Beccali, G.; Cellura, M.; Marvuglia, A. POEMS: A case study of an Italian wine-producing firm. Environ. Manage. 2006, 38, 350-364.

3. Colman, T.; Paster, P. Red, White and "Green": The Cost of Carbon in the Global Wine Trade; Working paper; American Association of Wine Economists: New York, NY, USA, 2007.

4. Environmental Product Declaration. Bottled Red Sparkling Wine. Validated Environmental product declaration $\mathrm{N}^{\circ}$ S-P-00109. Available online: http://gryphon.environdec.com/data /files/6/7505/EPD\%20S-P-00109\%20ingl-2008-def.pdf (accessed on 15 October 2012).

5. Environmental Product Declaration, Bottled Organic Red Sparkling Wine. Validated Environmental Product Declaration $\mathrm{N}^{\circ}$ S-P-00119. Available online: http:/gryphon. environdec.com/data/files/6/7521/EPD_Fratello\%20Sole_english\%202008-def.pdf (accessed on 15 October 2012).

6. Gonzalez, A.; Klimchuk, A.; Martin, M. Life Cycle Assessment of Wine Production Process: Finding Relevant Process Efficiency and Comparison with Eco-Wine Production; Report; Royal Institute of Technology: Stockholm, Sweden, 2006.

7. Institut Français de la Vigne et du Vin. Bilan carbone: de la vigne a la bouteille. 2007. Presentation. Available online: http://www.vignevin-sudouest.com/publications/itv-colloque/ documents/COLLOQUE_bilan-carbone-vigne-bouteille.pdf (accessed on 15 October 2012). 
8. Niccolucci, V.; Galli, A.; Kitzes, J.; Pulselli, R.M.; Borsa, S.; Marchettini, N. Ecological footprint analysis applied to the production of two Italian wines. Agr. Ecosyst. Environ. 2008, 128, $162-166$.

9. Pizzigallo, A.C.I.; Granai, C.; Borsa, S. The joint use of LCA and emergy evaluation for the analysis of two Italian wine farms. J. Environ. Manage. 2008, 86, 396-406.

10. Point, E.V. Life cycle environmental impacts of wine production and consumption in Nova Scotia, Canada. Master Thesis, Dalhousie University, Halifax, Nova Scotia, Canada, 2008.

11. Boudaoud, N.; Eveleigh, L.; Ruledge, D. Reconnaissance des Arômes et Nez Électronique. Ingénierie Analytique pour la Qualité des Aliments; Report; Institut National de Recherche en Agronomie (INRA): Versailles, France, 2003.

12. Marin, A.; Jorgensen, E.; Kennedy, J.; Ferrier, J. Effects of bottle closure type on consumer perceptions of wine quality. Am. J. Enol. Viticult. 2007, 58, 182-191.

13. Struijs, J. SimpleTreat 3.0: A Model to Predict the Distribution and Elimination of Chemicals by Sewage Treatment Plants; Report; National Institute of Public Health and the Environment: Bilthoven, The Netherlands, 1996.

14. Frischknecht, R.; Jungbluth, N.; Althaus, H.; Doka, G.; Dones, R.; Heck, T.; Hellweg, S.; Hischier, R.; Nemecek, T.; Rebitzer, G.; et al. The ecoinvent database: overview and methodological framework. Int. J. Life. Cycle. Ass. 2005, 10, 3-9.

(C) 2012 by the authors; licensee MDPI, Basel, Switzerland. This article is an open access article distributed under the terms and conditions of the Creative Commons Attribution license (http://creativecommons.org/licenses/by/3.0/). 